\title{
Using mushroom-forming fungi in preventing and reducing mycotoxins in cereal products
}

\author{
Uso de macromicetos para prevenir y reducir las micotoxinas \\ en productos de cereales
}

\author{
Jean-Michel Savoie ${ }^{1}$, Gerardo Mata ${ }^{2}$,Vessela Atanasova Penichon ${ }^{1}$, Marie Foulongne-Oriol ${ }^{1}$ \\ ${ }^{1}$ INRAE, MycSA, CS20032, 33882, Villenave d'Ornon, France. \\ ${ }^{2}$ Red Manejo Biotecnológico de Recursos, Instituto de Ecología, Carretera antigua a Coetepec 351, El Haya, C.P. 91073, Xalapa, \\ Veracruz, Mexico.
}

\section{RESUMEN}

Antecedentes: El control biológico de las enfermedades de los cereales causadas por hongos micotoxigénicos forma parte de los métodos alternativos a desarrollar para asegurar la producción de alimentos y forrajes, debido a los efectos negativos que estos hongos tienen sobre el rendimiento de los cultivos y su producción potencial de micotoxinas.

Objetivo: Actualizar el conocimiento sobre el potencial de los hongos formadores de hongos como agentes de control biológico de especies de hongos micotoxigénicos, actuando como: antagonistas en residuos de cultivos, fuente de extractos activos con propiedades antifúngicas y/o antimicotoxinas y como agentes detoxificantes en procesos de fermentación en estado sólido en cereales contaminados.

Métodos: Se realizó una revisión bibliográfica de los trabajos publicados, analizando los temas principales, así como las especies con mayor potencial como agentes de control biológico de los hongos micotoxingénicos.

Resultados y conclusiones: Los macromicetos se podrían usar como antagonistas en residuos de cultivos o granos, como fuentes de extractos activos con propiedades antifúngicas y/o antimicotoxigénicas y como agentes desintoxicantes. Una integración de estos tres potenciales da lugar a un proceso amigable con el medio ambiente para la producción de granos seguros y hongos comestibles.

Palabras clave: aflatoxinas, Aspergillus, cereales, Fusarium, hongos, tricotecenos

\section{ABSTRACT}

Background: Biological control for cereal diseases caused by mycotoxigenic fungi is part of the alternative methods to be developed to secure food and feed production, recognizing the negative effects these fungi have on crop yield and their potential production of mycotoxins.

Objective: Update recent knowledge about the potential of mushroom-forming fungi as biological control agents of mycotoxigenic fungi species, acting as antagonists on crop debris, as source of active extracts with antifungal and/or antimycotoxin properties and as detoxifying agents in solid-state fermentation processes of contaminated cereals.

Methods: A literature review of the published works was carried out, the main topics were analyzed, as well as the species with the greatest potential of biological control agents of mycotoxingenic fungi.

Results and conclusions: Mushroom forming fungi could be used as antagonists on crop debris or grains, as sources of active extracts with antifungal and/or antimycotoxin properties, and as detoxifying agents. An integration of these three potentials gives rise to an environment friendly process for production of both safe grains and edible mushrooms.

Keywords: aflatoxins, Aspergillus, cereals, Fusarium, mushrooms, trichothecenes

\section{ARTICLE HISTORY}

Received 30 July 2019 / Accepted 17 December 2019

Published on line: 31 December 2019

\section{CORRESPONDING AUTHOR}

Ju Jean-Michel Savoie, jean-michel.savoie@inra.fr

ORCID: 0000-0002-1427-0293 


\section{INTRODUCTION}

World cereal production increases continuously since several years, but there are subsequent losses due to contamination of produced grains by heavy metals, pesticides and mycotoxins rendering crops not suitable as food. Mycotoxins are naturally occurring secondary metabolites, produced by filamentous fungi that are toxic to humans and animals. Consumption of food containing high levels of these contaminants may cause illness. Most of these molecules are difficult to degrade; they resist high temperatures and chemicals. They are gaining worldwide attention because of the significant economic losses associated with their effects on animal and plant productivity, human health, and national and international trade.

Fusarium Head Blight (FHB) of small-grain cereals such as wheat and barley and Gibberella Ear Rot (GER) and Fusarium Ear Rot (FER) of maize are three devastating fungal diseases affecting crops worldwide. They produce the so-called field mycotoxins, zearalenone (ZEA), trichothecenes (TCTB, among which deoxynivalenol (DON) is the best known, and TCTA), and fumonisins (FB). The mycotoxins accumulate in the grains themselves, even in healthy looking ones with apparent good quality. Depending on the climatic conditions, the occurrence and level of contamination at harvest can be high.

Cereals and maize are also particularly sensitive to mycotoxin accumulation during storage. Storage mycotoxins are produced after harvest, by fungi of the genus Aspergillus and Penicillium in poor storage and ventilation conditions in silos. The main storage mycotoxins are aflatoxins and ochratoxins. Under certain climatic conditions, Aspergillus spp. and aflatoxin contamination begins in the field on maize. With the expected evolution of the climate in Europe, it is likely that field contaminations will develop significantly (Battilani et al., 2016). The aflatoxins are considered to be the most toxic of the mycotoxins, aflatoxins B1, B2, G1 and G2 being the principal aflatoxins of concern. They are produced by Aspergillus fumigatus and A. parasiticus. Ochratoxins are produced by $A$. ochraceus and related species, A. niger, as well as Penicillium verrucosum and certain other Penicillium species (Rodrigues, 2016).

Minimisation strategies for mycotoxins have included the use of relatively resistant varieties and good pre-harvest agricultural practices. Fungicides are frequently applied to manage the contamination of grains by Fusarium spp. or Aspergillus spp., but their efficacies are generally lower than $50 \%$ (Haidukowski et al., 2005; Loos et al., 2004). In addition, the effect of fungicides is rarely statistically significant when addressing grain contamination by mycotoxins. Mycotoxin production is suspected to be part of the adaptive response of the fungus to stressful conditions such as exposure to antifungal compounds (Ponts, 2015; Martins et al., 2016), and the accumulation is modulated by complex interactions between different fungal species (Scarpino et al., 2015). This explains observations such as increasing mycotoxin levels in rice grain treated with tebuconazole in field conditions (Dors et al., 2013), or the induction of the production of DON by strobilurins during in vitro studies (D'Mello et al., 2001).

Another drawback with current fungicides is the development of resistances, including resistance to synthetic fungicides that mimic natural fungicides. Strobilurins are a recent example of synthetic fungicides which application has led to the emergence of resistant fungal strains (Walker et al., 2009). Using successively different molecules with different physiological targets in pathogenic fungi is an accepted strategy for limiting the development of resistances. Unfortunately, the catalogue of available efficient molecules is limited. Compounds that inhibit mycotoxin production without inhibiting fungal growth may be useful for mycotoxin control without incurring a rapid spread of resistant strains. Consequently, new molecules with various activities are needed in the near future. In addition, nowadays, consumers and industry ask for environment friendly solutions to tackle the problems of plant pathology and food safety due to mycotoxins. In this context, searching for natural compounds to control fungal pathogens of plants and their production of mycotoxins is a challenge shared by research institutes and actors of agriculture.

Avoiding the primary contamination of plant by minimising the inoculum is another strategy. The most important sources of inoculum are ascospores, from the sexual stage, and macroconidia, from the anamorph stage. Chlamydospores and hyphal fragments can also act as sources of inoculum (Leplat et al., 2013). They mainly originate from crop debris remaining on soil after harvest of previous diseased crop. Toxigenic Fusarium or Aspergillus species can survive and multiply on maize stubble or small grain cereal straw and soil for 
several years. Crop rotation, crop residue management and biological control by treating the debris with antagonists are levers to minimize this inoculum (Sarrocco and Vannacci, 2018). Biocontrol agents acting as an antagonist, a mycoparasite and a competitor for natural substrates have been proposed (Xue et al., 2014; Palazzini et al., 2017). Microbial decomposition of crop residues is a natural process, which can be supported by adding stimulating nutrients or selected microorganisms for starving the niche of the inoculum.

Biological postharvest treatments for mycotoxin removal might represent a promising strategy to decrease mycotoxin content in contaminated grains (McCormick, 2013). Most of the microorganisms able to modify or metabolise field and storage mycotoxins are bacteria or yeasts (Martínez Tuppia et al., 2017; Wilson et al., 2017; Zhu et al., 2017; Peng et al., 2018), but filamentous fungi can also detoxify ochratoxins (Chen et al., 2018) or aflatoxins (Scarpari et al., 2014).

A mushroom forming fungus is defined as a macrofungus with a distinctive fruiting body that is large enough to be seen with the naked eye and to be picked up by hand, and can be either a Basidiomycete or an Ascomycete, aerial or underground (Chang and Miles, 1992). They generally colonize complex substrates for long times or form mycorrhizas. Among the abundant biodiversity of mushroom forming fungi, over 2,300 wild useful species have been identified, and more than 40 species are currently cultivated for producing food (Savoie et al., 2013). Most of the cultivated species are white rot fungi degrading lignocellulose organic matter. As white rot fungus, many mushroom forming fungi might have ability to compete effectively for the available nutrients in the ecological niche of crop debris on soil, and in this way colonise it and exclude the pathogen. It seems very likely that mushroom forming fungi do contain compounds with important biological properties due to the deep history of interactions between fruit bodies and potentially fungivorous animals or fungal pathogens (Largeteau and Savoie, 2010; Money, 2016). The vegetative mycelia need also antibacterial and antifungal compounds to survive in their natural environments.

We propose here a survey of potential of mushroom forming fungi as biological control agents of mycotoxigenic fungi, acting: (i) as antagonists on crop debris for reducing primary inoculum of mycotoxigenic fungi in fields, (ii) as source of active extracts with antifungal and/or antimycotoxin properties that could be used for controlling the accumulation of mycotoxin during the cultivation period and at storage of grains, (iii) as detoxifying agents in solid-state fermentation processes of contaminated cereals. The objectives are to highlight the opportunities to use mushroom forming fungi to prevent and reduce mycotoxins in cereal products, and to point the remaining challenges to be faced for the development of an integrated mycotoxin management in cereals using mushroom properties.

\section{COMPETITION ON CROP DEBRIS}

Infected crop debris staying on or in soils between two crops are the main inoculum source of Fusarium spp. Chlamydospores containing macroconidies allow Fusarium species to survive unfavourable conditions and thus to overwinter in soil or on crop residues until suitable temperature and humidity facilitate a new cycle of infections. In the sexual cycle of F. graminearum, perithecia on the crop residues are abundant in spring, as warm moist weather conditions are favourable for their maturation, and they release ascospores (Shah et al., 2018). Treatment of crop debris to reduce Fusarium primary inoculum in fields is one of the biocontrol strategy that is subject of work. Microorganisms accelerating residue degradation and/or being antagonistic against F. graminearum can be used (Legrand et al., 2017). As an example, the endophytic fungus Clonostachys rosea (formerly known as Gliocladium roseum) is a soil-borne ascomycete that exhibits suppressing ability of F. graminearum perithecial production when applied on crop residues (Xue et al., 2014). Several saprophytic fungi with good ability to colonise wheat straws or maize stalks and to suppress sporulation of pathogenic Fusarium spp. had been selected for their potential as biocontrol agents. Their efficiency for reducing colonisation of stalk pieces by pathogenic Fusarium spp. were sometimes significant, but not consistent (Luongo et al., 2005). For being efficient, an antagonist has to be present in sufficient quantity at the right time and place and to use nutrients more efficiently than the pathogen in case of exploitation competition (Legrand et al., 2017).

White-rot fungi are basidiomycetes that are capable of degrading the lignin component of lignocellulose substrates in addition to cellulose and hemicelluloses and are suitable for the colonization and degradation 
of wood and forest litters. They play an important role in the cycling of carbon and other elements. Most of the edible mushrooms that are cultivated on agricultural by-products (straw, stalk, wood ships, etc.) are white rot fungi. We postulate here that white rot fungi inoculated on crop debris would exploit them efficiently and deprive Fusarium species of nutrients in this niche. The first challenge to be addressed is the inoculation of crop debris on soils (Legrand et al., 2017). The use of cultivated mushroom species has benefits. Due to the life cycle of mushroom forming fungi, spores have to be collected from fruiting bodies, which could be fastidious to obtain. In edible mushroom cultivation, primary mycelium can be obtained from germination of spores, from a piece of a specific fruiting body, or from several germplasm providers. For producing inoculum that is usually called the spawn, the primary mycelium is developed on sterilized cereal grain (wheat, rye, millet or sorghum) (Sanchez, 2004). The mycelium-coated grains are then mixed with various lignocellulosic wastes at rates varying from 0.8 to $8 \%$ depending on the species and conditions, and the mycelium can rapidly colonize the substrate from a grain that is a protecting and nutritive habitat. Adding several lignocellulosic materials in the spawn improved the competitiveness of the mycelium by increasing the number of inoculation points and inducing enzymatic complexes for breaking down lignocelluloses (Mata et al., 1998). Mixing this spawn with crop debris on the soils could be a way to introduce the antagonist of Fusarium spp. Spawn making companies already exist in various countries and would rapidly be able to produce inoculum for the treatment of crop debris in fields if this treatment is adopted.

The outcome of the competition between white rot mushroom and Fusarium species will depend on the composition of the plant debris, the climatic conditions (temperature, water availability, relative concentrations of $\mathrm{O}_{2}$ and $\mathrm{CO}_{2}$ ) and the interaction with other microorganisms present on the debris. Changes in these factors can reverse interaction outcomes because different species display contrasting sensitivities and/ or patterns of response to these variables (Hiscox et al. 2018). Generally, $a_{w}$ has a greater influence on fungal growth than temperature but $a_{w}$ and temperature interact. Regarding water availability $\left(a_{w}\right)$ and temperature, there is some information available for both mycotoxinogenic fungi and white rot mushrooms
For Fusarium graminearum, maximum growth rates were obtained at the highest $a_{w}$ and $25^{\circ} \mathrm{C}$ and no or very slight growth was observed at $5{ }^{\circ} \mathrm{C}$, regardless of $a_{w}$ levels assayed (Ramirez et al., 2006). The minimum $a_{w}$ for growth was estimated to be 0.869 and 0.854 for $F$. verticillioides and F. proliferatum, respectively (Samapundo et al., 2005), but at $15{ }^{\circ} \mathrm{C}$ no growth of $F$. verticillioides occurred at $a_{w}$ lower than 0.95 (or matric water potential -7.0 MPa) (Jurado et al., 2008). Matric potential refers directly to forces required to remove water bound to the matrix (soil or plant debris). From the work of Marin et al. (1995) we extrapolate that at high $a_{w}(>0.98)$, growth at $15{ }^{\circ} \mathrm{C}$ represented $45 \%$ and $55 \%$ of growth at $25^{\circ} \mathrm{C}$ for F. moniliforme and F. proliferatum respectively, since growth at $4{ }^{\circ} \mathrm{C}$ represented $16 \%$ and $28 \%$ of growth at $15{ }^{\circ} \mathrm{C}$ for F. moniliforme and F. proliferatum respectively. For three Aspergillus flavus strains, the minimum $a_{w}$ needed for mycelial growth was 0.91 at 25 and $37^{\circ} \mathrm{C}$. At $15{ }^{\circ} \mathrm{C}$, only one isolate grew, and it was at $0.99 a_{w}$ (Lahouar et al., 2016). For white rot mushrooms, linear growth rate of three species of Pleurotus (oyster mushroom) at $15{ }^{\circ} \mathrm{C}$ was measured to be 36 to $64 \%$ that at $25^{\circ} \mathrm{C}$. It was 62 $\%$ for Lentinula edodes, shiitake (Zervakis et al., 2001). This highlights that mushroom forming fungi withstand better low temperatures than the mycotoxigenic fungi. Mushroom species have large geographic ranges, and adaptation of geographical populations and/or varieties of the species to different climates and habitats could be expected. As an example, Agaricus bisporus (button mushroom) is known to extend from the boreal region of Alaska to the equatorial climate of Congo and from coastal dunes to mountains of above 3000 m elevation (Largeteau et al., 2011). We postulate that it will be easy to select mushroom species and strains that are competitive for the colonisation of crop debris at temperatures below $15{ }^{\circ} \mathrm{C}$, when mycotoxigenic fungi are inactive.

Basidiomycetes are known to be more sensitive to changes in water potential than ascomycetes. The optimum growth of various wood decay basidiomycetes, including Pleurotus ostreatus was measured between 0.999 and $0.990 a_{w}$ (water potential -0.1 to $-1.4 \mathrm{MPa}$ ) and growth ceased between -0.97 and $0.95 a_{w}$ (Magan et al., 1995). For Agaricus bisporus and A. bitorquis, -3 $\mathrm{MPa}\left(0.985 \mathrm{a}_{\mathrm{w}}\right)$ was found to stop growth, and growth decreased below -1.0 MPa (0.990 $\left.a_{w}\right)$. In mushroom cultivation substrates based mainly of cereal straw, this 
favourable water potential is obtained with moisture contents in the range 60-80 \% (Philippoussis and Diamantopoulou, 2011). Compared to mycotoxigenic fungi, mushroom forming fungi are less tolerant to water stress due to low water potential and would be less competitive on plant debris under dry conditions.

Finally, the strength of white rot mushrooms for colonizing the crop debris in intercrops and exclude mycotoxigenic fungi is the strong capacity to breakdown the lignocellulosic material and their better adaptation to low temperature, but their weakness is their need of higher values of water availability for expressing their potential of colonisation. The feasibility of the proposed treatment of crop debris to reduce primary inoculum of mycotoxigenic fungi in fields, have to be experimented in microcosms and in fields. The efficiency of a large diversity of mushroom species either inoculated after harvest or introduced at the following spring could be tested.

\section{ANTIFUNGAL COMPOUNDS FROM MUSHROOM FOR- MING FUNGI ACTIVE AGAINST MYCOTOXIGENIC FUNGI IN CEREALS}

In addition to exploitation competition through resource depletion and physical exclusion, mushroom-forming fungi may act by interference competition through antibiosis, which might reinforce their ability to reduce the inoculum reservoir. In a review of the literature from 1999 to 2012 on antifungal activity of mushroom extracts and isolated compounds, the authors found that 52 species had been reported for their antifungal properties (Alves et al., 2013). More than 80 $\%$ are edible mushrooms, since their extracts might be generally be recognized as safe for use. As an example, ethanolic extracts of Hydnum repandum, a mycorrhizal species commonly known as the sweet tooth or hedgehog mushroom and broadly distributed in Europe and Asia, had strong antifungal effects on various Fusarium species (Spremo et al., 2017).

Most studies on mushrooms with antifungal activity were on crude or partially simplified extracts without identification of the compounds responsible for this property (Alves et al., 2013). Bioactive substances isolated from higher fungi belong to different chemical groups: (i) secondary metabolites (acids, terpenoids, polyphenols, sesquiterpenes, alkaloids, lactones, sterols, metal chelating agents, nucleotide analogues and vitamins) ii) proteins and glycoproteins; and (iii) high molecular mass polysaccharides (Erjavec et al., 2012). Some specific mushroom $\beta$-glucans are already used in clinical treatment for their antitumor and immunomodulatory properties, and are known as elicitors of plant defence response (Ryan, 1987), but they have no direct antifungal activity. Recently volatile compounds from edible mushrooms have been proposed as safe agents for controlling fungal diseases (Oka et al., 2015). Most investigations with mushroom metabolites have been on antagonistic effect to human pathogens for the therapeutics of human disorders, and less on the plant disease control (Chen and Huang, 2009).

Bioactive proteins from mushroom forming fungi with activity against mycotoxigenic species

A dozen of bioactive proteins and protein extracts from mushrooms have been selected for their antifungal activity on several species (Erjavec et al., 2012). In a recent overview of the biocontrol properties of Basidiomycetes, Sivanandhan et al. (2017) inventoried 15 known antifungal active compounds, half were antifungal proteins. As an example of fungal proteins that have been tested in the field of agricultural crop protection, Tamavidins are biotin-binding proteins from the oyster mushroom Pleurotus cornucopiae that can be expressed in transgenic rice and, as such, they provide resistance to the important rice-pathogenic fungus Magnaporthe oryzae (Takakura et al., 2012). Homologous to genes coding for Tamavidins were found also in Galerina marginata (poisonous), Hypholoma sublateritium (edible, cultivable) (Bleuler-Martinez et al., 2012). However, humans and animals require biotin to be supplied in the diet and biotin deficiency that may result to an exposure to biotin-binding proteins can lead to developmental delays in children, or hair and skin abnormalities in affected individuals (Dakshinamurti et al., 2017).

To our knowledge, antifungal proteins from cultivable edible mushrooms have not been tested for their activity against mycotoxigenic Fusarium species. However, since several years, a group at the China Agricultural University works on mushroom proteinaceous compounds with biological activities, including antifungal activity against $F$. oxysporum, a soil born pathogens with a broad host range ( $\mathrm{Ng}$ et al., 2016) (Table 1). Ganodermin from the medicinal mushroom Ganoderma lucidum (Wang and Ng, 2006), Eryngin from 
Pleurotus eryngii (Wang and Ng, 2004), Pleurostrin from Pleurotus ostreatus (Chu et al., 2005) and Hypsin, from Hypsizigus marmoreus (Lam and Ng, 2001a), were shown to inhibit mycelial growth of $F$. oxysporum and other fungal plant pathogens. Hypsin and several other mushroom peptides or proteins having different molecular masses and $\mathrm{N}$-terminal sequences are ribosom inactivators (Lam and $\mathrm{Ng}, 2001$ a): Pleuturegin from sclerotia of Pleurotus tuberingium (Wang and $\mathrm{Ng}, 2001)$, Lyophilin from Lyophillum shimeji (Lam and $\mathrm{Ng}, 2001 \mathrm{~b})$, Flammulin and Velutin, from Flammulina velutipes (Wang and Ng, 2000; Wong et al., 2010), Agrocybin from Agrocybe cylindracea (Ngai et al., 2005), Lentin from Lentinula edodes (Ngai and Ng, 2003), and Cordymin from Cordyceps militaris (Wong et al., 2011) are other mushroom proteins with antifungal properties that showed no effect on Fusarium oxysporum or Aspergillus fumigatus when tested, but they could be tested against mycotoxigenic Fusarium species and their production of mycotoxins.

Defensins are cysteine-rich antimicrobial peptides that may also have antifungal activity. Defensins are common in vertebrates, but fungi, plants, and many invertebrates produce defensin-like peptides structurally similar to the $\beta$-defensins from vertebrates (Silva et al., 2014). Defensins are frequently reported to induce membrane permeabilization of fungal cells (Thevissen et al., 1996), or to induce deposition of chitin on the tips of growing hyphae and consequently retard hyphal growth (Lin et al., 2010). Copsin from the mushroom Coprinopsis cinerea is a famous antibacterial defensin (Essig et al., 2014). There is a potential for identifying new defensins with antifungal and anti mycotoxin properties in mushroom forming fungi.
Lectins form one major group of glycan binding proteins and can be relatively specific depending on their composition, site specific modifications and tertiary structure of the glycan. Chitin in cell wall of fungi might be the target of antifungal lectins. Several plant lectins have antifungal activities against Fusarium species (Mohsen et al., 2018). Nikitina et al. (2017) recently reviewed lectins from mycelia and fruiting bodies of basidiomycetes. The ability to synthesize lectins is widespread among higher basidiomycetes and their hemagglutinating activity is species and strain dependent (Mikiashvili et al., 2006). Carbohydrate specificity also depends on lignocellulosic growth substrate used for producing mushrooms. It is possible to regulate lectin production and obtain preparations with different carbohydrate specificities by substitution of lignoceIlulosic material and strains (Davitashvili, et al., 2008; 2011). The development stage of mushroom forming fungi is also to be taken into account. In P. ostreatus, the mycelial lectins were mostly specific for mannose, whereas the highest inhibition toward the fruit body lectins was obtained with $\mathrm{N}$-acetyl-d-glucosamine and $\mathrm{N}$-acetyl-d-galactosamine for one lectin fraction and with galactose for other ones (Davitashvili, et al., 2010). In mushrooms, lectins are factors of the interactions with other fungi. The recognition and binding of the A. bisporus fruiting body lectin to Lecanicillium fungicola cell wall glucogalactomannan contributes to the development of the dry bubble disease on the button mushroom (Bernardo et al., 2004). Lectins of L. edodes either stabilize or activate laccases produced by the fungus (Vetchinkina et al., 2008). There is no clear report on mushroom lectins with antifungal activities against mycotoxigenic fungi, but due to their diversity,

TABLE 1: Mushroom proteins active against Fusarium oxysporum that have been extracted from fruiting bodies of mushroom forming fungi

\begin{tabular}{|c|c|c|c|c|c|}
\hline NAmE & ORIGIN & Activity & Molecular MASS KDA & $\begin{array}{l}\text { IC50 OR ACTIVE CON- } \\
\text { CENTRATION TESTED }\end{array}$ & REFERENCES \\
\hline Hypsin & Hypsizigus marmoreus & Ribosone-inactivation & 20 & $14.2 \mu \mathrm{M}$ & Lam and $\mathrm{Ng}$, 2001a \\
\hline Alveolarin & Polyporus alveolaris & Ribonuclease or lectin & 28 & $120 \mu \mathrm{g} / 15 \mu \mathrm{L} /$ disc & Wang et al., 2004 \\
\hline Eryngin & Pleurotus eyngii & Thaumatin-like & 10 & $72 \mathrm{~g} / 12 \mu \mathrm{L} /$ disc & Wang and Ng, 2004 \\
\hline Trichogin & Tricholoma giganteum & Ribonuclease or lectin & 27 & $\begin{array}{c}16 \text { and } 80 \mu \mathrm{g} / 15 \mu \mathrm{L} / \\
\text { disc }\end{array}$ & Guo et al., 2005 \\
\hline Ganodermin & Ganoderma lucidum & Unknown+ & 15 & $12.4 \mu \mathrm{M}$ & Wang and Ng, 2006 \\
\hline CMP & Cordyceps militaris & protease & 12 & $>1.6 \mu \mathrm{M} /$ disc & Park et al., 2009 \\
\hline Unnamed & Pleurotus sajor-caju & ribonuclease & 12 & $30 \mu \mathrm{mol}$ on disc & Ngai and Ng, 2004 \\
\hline
\end{tabular}


the possibility of modulation by cultivation conditions and the known activities, they are good candidates as molecules for controlling these fungi and their production of mycotoxins.

Various enzymes are produced by mushroom forming fungi to explore and use their environment, and they may contribute to an antifungal activity. Several studies reported that enzymes playing critical roles in cell wall degradation of fungi could be used for controlling fungal pathogens in vitro (Deng et al., 2018). A protease from Trichoderma harzianum inhibits spore germination of Aspergillus flavus and A. fumigatus, and is proposed as a potential means of controlling fungal diseases (Deng et al., 2018). An isolated serine protease from a Streptomyces species proved to be active against Fusarium udum (Sing and Chhatpar, 2011). A large variety of proteases has been revealed in mushroom forming fungi and some show unique characteristics that could be exclusive to Basidiomycetes (Sabotič et al., 2007). Subtilases are a class of serine proteases ubiquitous in fungi where they play a role in nutrition acquisition or in host invasion by contributing to the digestion of the cuticles, but gene duplication and sequence diversification have likely resulted in functional diversifications of fungal subtilases beyond simple nutrient utilization (Li et al., 2017). A subgroup of subtilisin-like proteases from ascomycete and basidiomycete fungi, belonging to the pyrolysin family has been defined (Faraco et al., 2005). For instance, most proteases of the genus Pleurotus feature the characteristics of alkaline subtilases (Eisele et al., 2011). This makes mushroom forming fungi a large, untapped pool of novel proteases with potential for controlling mycotoxigenic fungi.

Beta-1,3-glucanases are considered to be one component of a broad generalised defence mechanism of plants against pathogen attack. Beta-1,3-glucanase from seeds of Jatropha curcas exerted in vitro antifungal activity against Rhizoctonia solani Kuha and Gibberella zeae (anamorph Fusarium graminearum) (Wei et al., 2005). Fungi also produce beta-1,3-glucanases that have a physiological role in cell division, differentiation and nutritional role related to mycoparasitic activity. Trichoderma harzianum is an antagonist of a large variety of plant pathogens. Among different mechanisms for antagonism, it is able to produce lytic enzymes for the degradation of the fungal cell wall to assimilate further the intracellular contents of its hosts. Both $\beta-1,3$-glucanase and $\alpha-1,3$-glucanase contribute to the antifungal activity (Ait-Lahsen et al., 2001; Benítez et al., 1998). These enzymes are produced in large quantities by vegetative mycelium of mushroom forming fungi that could be used as source of enzyme production or as direct antagonists of mycotoxigenic fungi.

Phenolic compounds from fruiting bodies of edible mushrooms, with potential of activity against mycotoxigenic fungi

Both flavonoids and phenolic acids are lipophilic and can diffuse through the fungal membrane to penetrate into the cell and interfere in metabolic pathways involved in cell wall and membrane structures or transmembrane transport (Ansari et al., 2013). The resistance to mycotoxin accumulation of some cultivars of cereals or maize has been correlated with their content of phenolic compounds having a role in inhibiting growth and/ or toxin production by fungi (Atanasova-Penichon et al., 2016).

Plant flavonoids have promising ability to inhibit spore development and limit mycelium hyphae elongation of plant pathogens (Mierziak et al., 2014). Flavones and flavanones were active against $F$. graminearum, $F$. culmorum, F. avenaceum with low half maximal inhibitory concentrations (IC50 <4.8 mM) (Atanasova-Penichon et al., 2016). Many reports ensure that mushroom contains flavonoids, but edible mushrooms such as $A$. bisporus and $P$. ostreatus have been shown unable to synthesize them because they do not have, in their genome, genes coding the main enzymes involved in their metabolic pathway. In addition, no significant absorption was noticed from fruiting bodies cultivated in flavonoid-enriched substrates (Gil-Ramírez et al., 2016). Phenolic acids can be divided into two major groups, derivatives of benzoic acid having C1-C6 backbone such as p-hydroxybenzoic or syringic acids, and derivatives of cinnamic acid having C3-C6 backbones, such as p-coumaric, caffeic, ferulic, chlorogenic acids (Ferreira et al., 2009). Ferulic acid and cinnamic acid were found to be more abundant in heads of FHB-resistant barley varieties than in those of susceptible ones, following F. graminearum inoculation (Bollina and Kushalappa, 2011). Atanasova-Penichon et al. (2016) reviewed the antioxidant secondary metabolites in cereals with potential involvement in resistance to Fusarium and mycotoxin accumulation. Their fungicidal efficiency has been characterized against different Fusarium species and the authors proposed a ranking of phenolic acids for their toxicity toward F. graminea- 
rum as follows: chlorogenic acid < p-hydroxybenzoic acid $<$ caffeic acid $<$ syringic acid $<$ p-coumaric acid $<$ ferulic acid. In fact, more lipophilic compounds display a more efficient antifungal activity on Fusarium graminearum (Ponts et al., 2011). However, it is noteworthy that a same phenolic acid can have contrasted effects, depending on the dose used, cultivation conditions and the species. For example, Fusarium verticillioides growth was significantly reduced at $20 \mathrm{mM}$ of ferulic acid, but it was stimulated at $1.0 \mathrm{mM}$ (Ferrochio et al., 2013), and F. langsethiae growth was reduced at 1.0 $\mathrm{mM}$ but stimulated at $0.5 \mathrm{mM}$ (Ferruz et al., 2016).

Phenolic acids are the main phenolic compounds in mushroom forming fungi that are proposed to be used as an easily accessible source of natural antioxidants (Nowacka et al., 2014). Recently, ethanolic extracts, known to be rich in phenolic compounds, from fruiting bodies of Hydnum repandum, and methanolic extracts of Stereum subtomentosum and Bjerkandera adusta, showed antifungal effects on F. verticillioides, F. proliferatum and F. graminearum (Spremo et al., 2017). Phenolic acids have been measured in various species, but depending on the analytical methods used, not all the phenolic acids had been searched in all the studied mushrooms. Table 2 shows data on mushroom contents for the six phenolic acids having fungicidal activity against $F$. graminearum according to Atanasova-Penichon et al. (2016).

Among the three compounds with the highest antifungal effect on F. graminearum, syringic acid had not been frequently searched in mushroom forming fungi, whereas p-coumaric acid was assayed in 69 and ferulic acid in 41 mushroom samples out 76 mushrooms analysed in the works reported in Table2. Both p-coumaric acid and ferulic acid were detected in $41 \%$ of the samples where they were searched. In table 2, the highest content of p-coumaric acid is for Psathyrella candolleana (66.4 $\mathrm{mg} \mathrm{kg}^{-1}$ ) collected in Turkey (Dündar et al., 2015). Agaricus arvensis, Lactarius indigo, Pholiota mutabilis, contain more than $25 \mathrm{mg}$ p-coumaric acid $\mathrm{kg}^{-1}$. The highest contents of ferulic acid are in Boletus frostii (100 mg kg-1), an American species widely distributed, and in the cultivated oyster mushroom, Pleurotus ostreatus (20 $\mathrm{mg} \mathrm{kg}^{-1}$ ).

However, it is noteworthy that for a same species, significant differences in concentrations are reported in different articles. In Table 2, samples of A. bisporus were analysed in six different studies, and p-coumaric acid was found in only three samples (2 to $10 \mathrm{mg} \mathrm{kg}$ $\left.{ }^{1}\right)$. In a study comparing different white hybrids and a brown strain of $A$. bisporus grown simultaneously in an experimental facility (Gasecka et al., 2018), the concentration of p-coumaric acid was higher in the brown strain than in the white ones. Ferulic acid concentration in A. bisporus was 13 and $16 \mathrm{mg} \mathrm{kg}^{-1}$ in the studies reported by Geseacka et al. (2018) and Palacios et al. (2011), whereas it was not detected in two other studies (Kim et al., 2008; Muszyńska et al., 2015).

Cinnamic acid has been detected at concentrations higher than $10 \mathrm{mg} \mathrm{kg}^{-1}$ in Agaricus subrufescens (Kim et al., 2008), A. arvensis, A. sylvicola, A. romagnesii (Barros et al., 2009), Boletus edulis (Yahia et al., 2017), Ganoderma lucidum (Heleno et al., 2013); fruiting bodies of Cantharellus cibarius and Picipes badius (formely Boletus badius) (Muszyńska et al., 2015), Hygrophorus agathosmus and Tricholoma sulphureum (Vaz et al., 2011).

Phenolic acids from mushrooms have also antifungal potentials against producers of Aflatoxins or Ochratoxins. Methanolic extracts from fruiting bodies of Cordiceps militaris containing p-hydroxybenzoic acid and cinnamic acids revealed antifungal potential against $A$. fumigatus and A. ochraceus (Reis et al., 2013). P-hydroxybenzoic and cinnamic acids identified in Ganoderma lucidum revealed antifungal activity against Aspergillus fumigatus, A. ochraceus, A. niger, with higher activity than the fungicides used as standards (Heleno et al., 2013). Methanolic extracts containing these compounds proved to have higher antioxidant potential than corresponding water extracts rich in polysaccharides (Heleno et al., 2012).

The present survey of the literature shows that significant levels of phenolic compounds can be found in mushroom forming fungi, but the available data varies between authors for a same species and it is difficult to select a priori mushroom species with an interesting composition in phenolic acids that could be a source of extracts as anti-Fusarium product. Apart from differences in analytical methods between laboratories expertise, the quality of the samples analysed might be affected by the development stage of the mushroom, the storing delay and conditions before analyses, the ecosystems they come from or the substrates and conditions used for their cultivation, intraspecific variations due to genetic diversity. Further screenings for obtaining extracts with interesting 
phenolic composition and antifungal activity should be on mushroom species with high levels of available biodiversity that can be cultivated under controlled conditions, and for which strain selection are possible. This is the case of the cultivated edible mushrooms such as several species of Agaricus or Pleurotus. Selection of very efficient strains could be completed with improvement of their capacities by breeding programs that are currently performed on these species for other traits (Savoie et al. 2013).

TABLE 2: Phenolic acids concentrations in mushroom forming fungi

\begin{tabular}{|c|c|c|c|c|c|c|c|c|}
\hline \multirow[t]{2}{*}{ REFERENCES } & \multirow[t]{2}{*}{ MUSHROOM SPECIES } & \multirow[t]{2}{*}{ EDIBILITY } & \multicolumn{6}{|c|}{ Phenolic ACIDS (MG KG $\mathrm{KG}^{-1}$ ) } \\
\hline & & & $\begin{array}{l}\text { FERULIC } \\
\text { ACID }\end{array}$ & $\begin{array}{l}\text { P-COUMA- } \\
\text { RIC ACID }\end{array}$ & $\begin{array}{l}\text { SYRINGIC } \\
\text { ACID }\end{array}$ & $\begin{array}{l}\text { CAFFEIC } \\
\text { ACID }\end{array}$ & $\begin{array}{l}\text { P-HYDROXYBENZOIC } \\
\text { ACID }\end{array}$ & $\begin{array}{l}\text { CHLOROGE- } \\
\text { NIC ACID }\end{array}$ \\
\hline Barros et al., 2009 & Agaricus arvensis & edible & - & 48.7 & - & - & 70.1 & - \\
\hline Gasecka et al., 2018 & A. arvensis & - & 11 & 16 & nd & 13 & nd & 57 \\
\hline Muszyńska et al., 2015 & A. biporus & edible & nd & nd & - & - & 7.0 & - \\
\hline Kim et al., 2008 & A. bisporus & edible & nd & nd & nd & nd & nd & nd \\
\hline Reis et al., 2013 & A. bisporus & edible & - & 2.3 & - & - & nd & - \\
\hline Barros et al., 2009 & A. bisporus & edible & - & nd & - & - & 25.6 & - \\
\hline Palacios et al., 2011 & A. bisporus & edible & 16 & 10.4 & & 15.5 & 15.4 & 63.7 \\
\hline Gasecka et al., 2018 & A. bisporus (mean 7 strains) & edible & 13 & 8.7 & nd & 15.5 & 15.4 & 63.7 \\
\hline Gasecka et al., 2018 & A. bitorquis & edible & 11 & nd & nd & 14 & nd & 56 \\
\hline Gasecka et al., 2018 & A. campestris & edible & 18 & 11 & nd & 1 & 28 & nd \\
\hline Barros et al., 2009 & A. romagnesii & toxic & - & nd & - & - & 32.4 & - \\
\hline Gasecka et al., 2018 & A. silvaticus & edible & 10 & 15 & 34 & 3 & 18 & nd \\
\hline Barros et al., 2009 & A. silvicola & edible & - & 45.7 & - & - & 238.7 & - \\
\hline Gasecka et al., 2018 & A. subrufescens & edible & 14 & 5 & 56 & 22 & 15 & 62 \\
\hline Kim et al., 2008 & A. subrufescens (blazei) & edible & nd & nd & 22 & nd & nd & nd \\
\hline López-Vázquez et al., 2017 & Amanita caesarea & edible & - & - & - & - & - & 564.4 \\
\hline Yahia et al., 2017 & A. flavocconia & non-edible & 2.1 & nd & - & nd & 145.4 & nd \\
\hline Yahia et al., 2017 & A. pantherina & toxic & nd & nd & - & 257.6 & 90.0 & 36.9 \\
\hline Dundar et al., 2015 & Armillaria tabescens & edible & -- & 0.6 & 62.6 & nd & - & - \\
\hline Muszyńska et al., 2015 & Boletus badius & edible & 1.5 & 13.9 & - & - & 1.3 & - \\
\hline Dundar et al., 2015 & B. edulis & edible & - & 5.5 & 38.9 & 6.1 & - & - \\
\hline Yahia et al., 2017 & B. edulis & edible & nd & nd & - & - & 34.0 & nd \\
\hline López-Vázquez et al., 2017 & B. edulis & edible & - & - & - & - & - & 1001.7 \\
\hline Palacios et al., 2011 & B. edulis & edible & nd & 0.9 & - & 15.1 & 24.1 & 62.8 \\
\hline Yahia et al., 2017 & B. frostii & edible & 100.0 & nd & - & nd & nd & nd \\
\hline Yahia et al., 2017 & B. Luridus & edible & nd & nd & - & 53.0 & nd & 185.3 \\
\hline Palacios et al., 2011 & Calocybe gambosa & edible & 14.5 & nd & - & 14.9 & 11.3 & 63.0 \\
\hline Nowacka et al., 2014 & Calvatia excipuliformis & toxic & trace & 0.2 & - & nd & 2.19 & - \\
\hline López-Vázquez et al., 2017 & Cantharellus cibarius & edible & - & - & - & - & - & 108.2 \\
\hline Palacios et al., 2011 & C. cibarius & edible & 10.4 & nd & - & 16.3 & 15.7 & nd \\
\hline Muszyńska et al., 2015 & C. cibarius & edible & nd & nd & - & - & nd & - \\
\hline Nowacka et al., 2014 & Clitocybe cinerea & non-edible & trace & nd & - & nd & 4.5 & - \\
\hline Nowacka et al., 2014 & Coprinus micaceus & edible & nd & 6.0 & - & nd & 25.1 & - \\
\hline Reis et al., 2012a & Cortinarius caperatus & edible & - & nd & - & - & 25.9 & - \\
\hline Nowacka et al., 2014 & Cratarellus cornucopiodes & edible & trace & 0.3 & - & nd & 12.7 & - \\
\hline
\end{tabular}


concluye Tabla 2.

\begin{tabular}{|c|c|c|c|c|c|c|c|c|}
\hline \multirow[t]{2}{*}{ REFERENCES } & \multirow[t]{2}{*}{ MUSHROOM SPECIES } & \multirow[t]{2}{*}{ EDIBILITY } & \multicolumn{6}{|c|}{ Phenolic ACIDS (MG KG ${ }^{-1}$ ) } \\
\hline & & & $\begin{array}{l}\text { FERULIC } \\
\text { ACID }\end{array}$ & $\begin{array}{l}\text { P-COUMA- } \\
\text { RIC ACID }\end{array}$ & $\begin{array}{l}\text { SYRINGIC } \\
\text { ACID }\end{array}$ & $\begin{array}{c}\text { CAFFEIC } \\
\text { ACID }\end{array}$ & $\begin{array}{l}\text { P-HYDROXYBENZOIC } \\
\text { ACID }\end{array}$ & $\begin{array}{l}\text { CHLOROGE- } \\
\text { NIC ACID }\end{array}$ \\
\hline Palacios et al., 2011 & C. cornucopioides & edible & 14.0 & nd & - & nd & 6.3 & nd \\
\hline Vaz et al., 2011 & Fistulina hepatica & edible & - & nd & - & - & 41.9 & - \\
\hline Kim et al., 2008 & Flammulina velutipes & edible & 9 & nd & nd & 17 & nd & 26 \\
\hline Kim et al., 2008 & Ganoderma lucidum & edible & nd & nd & nd & nd & nd & nd \\
\hline Dundar et al., 2015 & Helvella leucopus & non-edible & - & 57.0 & nd & nd & - & - \\
\hline Dundar et al., 2015 & H. queletii & non-edible & - & nd & 4.6 & nd & - & - \\
\hline Vaz et al., 2011 & Hygrophorus agathosmus & edible & - & 8.6 & - & & nd & - \\
\hline Vaz et al., 2011 & H. olivaceo-albus & edible & - & nd & - & - & 7.4 & - \\
\hline Palacios et al., 2011 & H. marzuolus & edible & nd & 4.7 & - & 14.6 & 5.5 & nd \\
\hline Kim et al., 2008 & Inonotus obliquus & edible & 22 & nd & nd & nd & 263 & nd \\
\hline Nowacka et al., 2014 & Laccaria amnethystea & edible & nd & 1.9 & - & nd & 17.7 & - \\
\hline Palacios et al., 2011 & Lactarius deliciosus & edible & 11.4 & nd & - & 15.5 & 21.4 & 62.7 \\
\hline Barros et al., 2009 & L. delicious & edible & - & nd & - & - & 22.7 & - \\
\hline Yahia et al., 2017 & L. indigo & edible & nd & 30.5 & - & nd & 11.6 & 3.2 \\
\hline López-Vázquez et al., 2017 & L. indigo & edible & - & - & - & - & - & 222.4 \\
\hline Vaz et al., 2011 & L. salmonicolor & edible & - & nd & - & - & 3.4 & - \\
\hline Reis et al., 2012a & Lentinula edodes & edible & - & nd & - & - & 1.6 & - \\
\hline Kim et al., 2008 & L. edodes & edible & nd & nd & nd & nd & nd & nd \\
\hline Barros et al., 2009 & Lepista nuda & edible & - & 3.7 & - & - & 29.3 & - \\
\hline Barros et al., 2009 & Lycoperdon molle & edible & - & 4.0 & - & - & 41.7 & - \\
\hline Nowacka et al., 2014 & L. perlatum & edible & nd & 1.9 & - & nd & 3.7 & - \\
\hline Kim et al., 2008 & Phellinus linteus & edible & nd & nd & nd & 13 & 6 & 23 \\
\hline Nowacka et al., 2014 & Pholiota mutabilis & edible & trace & 29.1 & - & 1.4 & 24.8 & - \\
\hline Reis et al., 2012a & Pleurotus eryngii & edible & - & 1.0 & - & - & 0.1 & - \\
\hline Kim et al., 2008 & P. eryngii & edible & nd & nd & nd & nd & nd & nd \\
\hline Dundar et al., 2015 & P. ostreatus & edible & - & nd & 25.4 & 2.5 & - & - \\
\hline Reis et al., 2012a & P. ostreatus & edible & - & 0.8 & - & - & 1.6 & - \\
\hline Palacios et al., 2011 & P. ostreatus & edible & 20.2 & 11.1 & & nd & 4.7 & nd \\
\hline Kim et al., 2008 & P. ostreatus & edible & nd & nd & nd & nd & nd & 19 \\
\hline Dundar et al., 2015 & Psathyrella candolleana & edible & - & 66.4 & 12.5 & 3.2 & - & - \\
\hline Barros et al., 2009 & Ramaria botrytis & edible & - & nd & - & - & 14.0 & - \\
\hline Yahia et al., 2017 & Russula emetica & non-edible & 5.2 & nd & - & nd & nd & nd \\
\hline Yahia et al., 2017 & Sarcodon imbricatus & non-edible & nd & nd & - & nd & nd & 20.7 \\
\hline Barros et al., 2009 & S. imbricatus & edible & - & nd & - & - & 33.2 & - \\
\hline Kim et al., 2008 & Sparassis crispa & edible & nd & 37 & 5 & 18 & 34 & nd \\
\hline Yahia et al., 2017 & Strobilomyces floccopus & non-edible & nd & nd & - & 79.9 & 80.0 & nd \\
\hline Vaz et al., 2011 & Suillus collinitus & edible & & nd & - & - & 14.1 & - \\
\hline Vaz et al., 2011 & S. mediterraneensis & non-edible & & nd & - & - & 2.0 & - \\
\hline Barros et al., 2009 & Tricholoma acerbum & edible & & nd & - & - & 29.7 & - \\
\hline Dundar et al., 2015 & T. populinum & edible & & 4.2 & nd & 3.6 & - & - \\
\hline Vaz et al., 2011 & T. sulphureum & non-edible & & nd & - & - & 2.6 & - \\
\hline
\end{tabular}


Other specific compounds from mushroom forming fungi with antifungal activity

Several molecules with potential as fungicides has been identified and isolated from mushroom forming fungi. There are few examples with concern on mycotoxigenic fungi. Three are given bellow.

The first fungicides in the family of Strobilurins were isolated from wood-rotting mushroom fungi, including one called Strobilurus tenacellus and chemists synthetized and improved on these natural fungicides (Vincelli, 2012). Strobilurins act to inhibit the mitochondrial respiratory chain at the level of Complex III, which results in cellular oxidative stress triggered by electrons escaping from the respiratory chain, which can be detoxified by mitochondrial superoxide dismutase (Kim et al., 2007). Strobilurin fungicides were reported to be hardly effective on several occasions against different Fusarium species few years after their introduction, but natural resistance to trifloxystrobin has been shown in populations of F. graminearum (Dubos et al., 2011). Consequently, Strobilurins are not efficient for controlling these fungi.

Antimicrobial terpenoids are potentially present in many mushrooms forming fungi and cultivating mushrooms as biosources for these compounds is worth being studied (Shen et al., 2017). Rufuslactone from Lactarius rufus was found to inhibit the mycelial growth of $F$. graminearum (Luo et al., 2005), and chrysotrione A and B from Hygrophorus chrysodon showed moderate antifungal activity on $F$. verticillioides whereas they were more active for controlling another phytopathogenic fungus, Alternaria brassica (Gilardoni et al., 2007).

1-octen-3ol and 10-oxo-trans-8-decenoic acid are volatile secondary metabolites found in many mushrooms. They contribute to the "mushroom-like" aroma and possess antifungal activities against the mycotoxigenic fungus Penicillium expansum (Okull et al., 2003). This survey of potent antifungal compounds from mushroom forming fungi shows they are various, and some might be active against mycotoxigenic fungi. However, it is also worth finding natural compounds having an effect on the mycotoxin production for completing fungicide or fungistatic properties.

\section{ANTI-MYCOTOXIN COMPOUNDS FROM MUSHROOM FORMING FUNGI}

In this section, mushroom compounds with potential activity on the production of mycotoxins by Aspergillus spp. and other mycotoxigenic fungi have been discussed, with emphasis on phenolic compounds and antioxidants because they have been shown to inhibit the production of some mycotoxins.

\section{Mushroom extracts inhibiting the production of aflatoxins}

Published works on the control of mycotoxin production by mushroom-forming fungi are mainly for aflatoxins produced by Aspergillus parasiticus or A. flavus and lignocolous white rot fungi, Lentinula edodes, Trametes versicolor, Pleurotus spp. The polyketide aflato$x$ in is looked as a secondary defence system protecting the fungus from excess reactive oxygen species (ROS) (Hong et al., 2013). Production of aflatoxin was observed to be related to the peroxidation of the fungal cellular membranes and fatty acid $\beta$-oxidation in both the peroxisome and mitochondria (Maggio-Hall et al., 2005). That explains why antioxidants have been taken into consideration, and reported for their efficacy for controlling aflatoxin production (Zhao et al., 2018).

Culture filtrates of $L$. edodes were shown to be able to inhibit aflatoxin production by $A$. parasiticus with a direct relation between aflatoxin inhibition and $\beta$-glucan content of the lyophilised filtrates (Reverberi et al., 2005). Such extracts were shown to stimulate the antioxidant system of the mycelium by the induction of a transient and modulated oxidative burst perceived by ApyapA transcription factor of $A$. parasiticus (Reverberi et al., 2006). Bioactive compounds secreted in the culture filtrates of $T$. versicolor, as well as lyophilised solid of mycelium grown on agricultural residues, inhibited the production of aflatoxin in maize kernels inoculated with A. flavus (Scarpari et al., 2014). The Afyap1 transcription factor of $A$. flavus was involved (Scarpari et al., 2016).

For both L. edodes and T. versicolor, significant differences in aflatoxin inhibition rate among different tested isolates were evidenced, although the same cultural conditions were used. They were attributed to differences in quality rather than the quantity of the inhibiting compounds (Zjalic et al., 2006), but improvement of the yield of $\beta$-glucan production by $L$. edodes strains using oxidative stress inductors leaded to higher aflatoxin inhibiting capacity (Reverberi et al., 2004). In addition to mycelium, fruiting bodies can also be a source of active compounds. A water-soluble complex of polysaccharides possessing $\beta$ - $(1,4)$-glucan backbones and peptides extracted at high tempera- 
ture from fruiting bodies of $L$. edodes inhibited AFB1 production by $A$. flavus, with an IC50 of $<10 \mu \mathrm{g} \mathrm{mL}^{-1}$ (Li et al., 2015).

Finally, the efficacy of mushroom extracts as inhibiters of the production of aflatoxin is due, on the one hand, to the presence of compounds with intrinsic antioxidant activity and, on the other hand, to the stimulation of the antioxidant system of the toxigenic fungi.

\section{Mushroom extracts inhibiting the production of other mycotoxins}

Lentinula edodes extracts were also proposed to boost the antioxidant enzyme activity of a biocontrol agent and contribute to control patulin biosynthesis, promoting the antioxidant activity of Penicillium expansum on apples (Tolaini et al., 2010; Wang et al., 2013). They also can elicit and regulate the biosynthesis of ochratoxin A by Aspergillus ochraceus (Reverberi et al., 2008). Methanolic extracts from fruiting bodies of Agaricus boshui are also active against Penicillium verrucosum producing OTA (Reis et al., 2012b).

We did not find data on the regulation of the biosynthesis of Fusarium toxins by this kind of mushroom extracts. However, in addition to aflatoxin, ROS, antioxidants and Yap-like bZIP factors are also known to be involved in regulation of the biosynthesis of Fusarium mycotoxins such as trichothecenes, fumonisins and ZEN. Response to oxidative stress and fungal secondary metabolism are indeed intertwined. It seems likely that for instance, the production of DON and its acetylated derivatives is probably a part of an adaptive response to oxidative stress from the ROS produced by the host plant as an early defence mechanism in response to infection by F. graminearum (Ponts, 2015). Oxidative stress with $\mathrm{H}_{2} \mathrm{O}_{2}$ could be a pre-requisite for the biosynthesis of DON. Both stress responses and the regulation of DON synthesis are mediated by the transcription factor FgAP1 that activates the transcription of antioxidant enzymes (Montibus et al., 2013). A link was established between antioxidant and antiradical properties of flavonoids and their effects on trichothecenes production by F. culmorum and F. graminearum (Bilska et al., 2018). Microalgae phenolic extracts rich in chlorogenic acid showed antifungal and antimycotoxigenic activities (Scaglioni et al., 2018), as well as maize extracts do (Atanassova-Penichon et al., 2014). Synergic effect between different compounds present in the extracts also influences their antimycotoxigenic activity (Scaglioni et al., 2018). Natural antioxidants such as ferulic acid may contribute to limit the production of fumonisins in maize kernels (Picot et al., 2013).

\section{Phenolic compounds and antioxidant activity from mushrooms} inhibiting the production of mycotoxins

Antioxidant activities appeared above as regulators of the production of various mycotoxins and searching for mushroom forming fungi with high contents in antioxidants is of interest. Mushroom extracts with antioxidant properties might contribute both to fight the up regulation of synthesis of mycotoxins by oxidative stress (Zhao et al., 2018) and to protect against their toxicity (Da Sylva et al., 2018). Actually, mushrooms are currently proposed to be used as an easily accessible source of natural antioxidants mostly due to their richness in phenolic compounds, and have attracted much interest as functional foods. The total phenol concentration is currently measured in mushroom samples for an estimation of their potential as antioxidant in functional food. It is determined most of the time in extracts by the Folin-Ciocalteu's phenol reagent method (Savoie, 2008). Gil-Ramírez et al. (2016) who used a direct measurement of total phenolic compounds without extraction on 24 samples from 24 species belonging to 18 genera, reported values ranging from 1 to more than $14 \mathrm{mg}$ gallic acid equivalent (GAE) $\mathrm{g}^{-1}$ mushroom powder, depending on the species. For the button mushroom $A$. bisporus, total phenolic contents ranged from 1 to $16 \mathrm{mg} \mathrm{GAE} \mathrm{g}^{-1}$ when both white and brown strains, and both cultivars and wild strains were taken into account (Alvarez-Parrilla et al., 2007; Barros et al., 2009; Dubost et al., 2007; Gan et al., 2013; Gasecka et al., 2018; Gil-Ramirez et al., 2016; Palacios et al., 2011; Reis et al., 2012a; Savoie et al., 2008). Comparing these intraspecific and interspecific range shows the variability of the data and the necessity to characterize the factors responsible of variations in total phenolic contents.

The efficiency of selected phenolic acids to modulate in vitro the biosynthesis of mycotoxins has been demonstrated for various toxins. Ferulic, chlorogenic, and caffeic acids have been shown as efficient inhibitors of TCTB production by Fusarium graminearum and F. culmorum (Boutigny et al., 2009; Gauthier et al., 2016), TCTA by F. langsethiae and F. sporotrichioides (Ferruz et al., 2016), and fumonisins by F. verticillioides (Atanasova-Penichon et al., 2014; Beekrum et al., 2003). 
However, there is a strain and concentration dependent effect of phenolic acids on Fusarium toxin synthesis. Ferulic acid used at concentrations that did not affected the mycelial growth rate can either limit or enhance the accumulation of TCTB by F. graminearum (Boutigny et al., 2009; Ponts et al., 2011). In regards to synthesis of fumonisins, Ferrochio et al. (2013) showed that ferulic acid activated their production at low concentrations while inhibited it at higher ones.

Richness of mushroom extracts in phenolic compounds (Table 2) is discussed above. It is noteworthy that co-occurrence of several compounds are found in various works. Mixture of phenolic acids and other active compounds, as found in natural mushroom extracts, might have different potentials than single molecules. Whereas mixtures of phenolic compounds with antioxidant activities might limit the production of mycotoxins, some studies show that there was no clear correlation between the antioxidant properties of natural and natural-like phenolic compounds tested singly and their ability to inhibit fungal growth and mycotoxinogenic capacity of Fusarium culmorum (Pani et al., 2014). Other properties of the individual compounds due to their chemical structures and mode of action might have higher effects. The potential of a mushroom extract can only partly be predicted by its known composition, and it will have to be evaluated experimentally.

\section{DETOXIFICATION}

Biotransformation of mycotoxins performed with purified enzymes isolated from bacteria, fungi and plants has recently been reviewed (Loi et al, 2017). Laccases (E.C. 1.10.3.2 benzenediol: oxygen oxidoreducta$\mathrm{se}$ ) are an interesting group of $\mathrm{N}$ glycosylated multicopper blue oxidases that oxidize a large number of both phenolic and non-phenolic compounds that may be involved in degradation of aflatoxins. Most of the mushroom-forming fungi are producers of laccases. Motomura et al. (2003) reported a high aflatoxin B1 degradation activity from Pleurotus ostreatus in cultures at $25{ }^{\circ} \mathrm{C}$ and $\mathrm{pH} 4.0-5.0$, possibly linked to the enzymatic oxidation handled by laccases or peroxidases (Yehia, 2014). Treatments of maize seeds or milled seeds, with culture filtrates of Trametes versicolor rich in laccases activities, showed a significant degradation of aflatoxin B1 content after 7 days of the treatment (Scarpari et al., 2014). Aflatoxin $B_{1}$ treated with pure laccase enzyme from T. versicolor (and recombinant laccase produced by $A$. niger) was significantly metabolized to degradation products with chemical properties that vastly differ from the parent molecule. Concomitant significant loss of mutagenicity, as evaluated in the Salmonella typhimurium mutagenicity assay, was observed (Alberts et al., 2009). The degrading activity of Lac2 pure enzyme from $P$. pulmonarius towards aflatoxin was enhanced by the addition of natural phenolic compounds as redox mediators (Loi et al., 2016).

Concerning the degradation of other mycotoxins besides the above-mentioned activity towards aflatoxins, laccases are also able to degrade ZEN. This was shown with a T. versicolor preparation (Banu et al., 2013). The laccase-mediator system was used with a laccase from P. eryngii, for combined mycotoxin degradation in vitro. DON was not affected whereas AFB1, FB1, OTA, ZEN and T-2 toxin were at least partly degraded, as well as combinations of AFB1 and ZEN, but without relevant synergistic nor additive effects (Loi et al., 2018). In combination of FB1 and T-2 toxin, a strong additive effect was reported for T-2 toxin degradation whereas FB1 degradation was drastically reduced. Most of the cultivated edible mushrooms are white rot fungi, they are laccase producers and they degrade lignocellulosic substrate, which leaves a white rot residue during the degradation of lignin. Laccases extracted from mushrooms or cultivation substrates of white rot fungi mycelium have been used in the removal of many emerging contaminants that are difficult to decompose (Chang et al., 2018). Numerous laccase isoenzymes have been achieved in various species of fungi, with dissimilar physicochemical and kinetic properties. There are various laccase isoforms in a same fungal strain. These isoforms could be expressed at different phases of the fungal life cycle or under diverse cultivation conditions (Baldrian, 2006; Othman et al., 2018). It would be possible to select several ones with interesting activity for Fusarium mycotoxin degradation.

Solid-state fermentation process with edible white rot mushroom forming fungi for biological detoxification of aflatoxin $B_{1}$ and other mycotoxins is worth being developed. Methods of myceliation of agricultural substrates proposed for producing functional foods with health benefits (Kelly and Langan, 2013) could also contribute to mitigate the mycotoxin risk. This was recently tested at the laboratory scale by cultivating $P$. eryngii on a mixture containing corn con- 
taminated with aflatoxin $B_{1}$. The mycotoxin was degraded and edible fruiting bodies free of aflatoxin $\mathrm{B}_{1}$, or its metabolite aflatoxicol, were produced (Branà et al., 2017). The resulting detoxified cultivation substrate could also be used in feed rations. Agro-based spent mushroom substrate from Pleurotus spp. and Agaricus bisporus have been known to be suitable for applications of ruminant feedstock (Mohd Hanafi et al., 2018). Otherwise, many mushroom forming fungi can be cultivated on starch rich materials such as cereal grains in solid-state fermentation, and both nutrients and antioxidant activities of the cereals are enhanced after being fermented by edible mushrooms (Han, 2003; Han et al., 2005; Zhai et al., 2015). The process could also have consequences on the final content in mycotoxins. Grains with low concentrations of mycotoxins would be cleaned up and enriched in nutrients after solid-state fermentation, and could be used as food.

\section{CONCLUSION}

Within this review, we were interested of the potential of mushroom-forming fungi for mitigation of mycotoxin contamination in cereal products. Many mushroom species are a food source and exhibit a rich source of bioactive compounds in preventing or treating various types of human and animal diseases. Some have been proposed as source of antifungal compounds against phytopathogenic fungi. A couple of species are subjects of works in progress for their potential as biocontrol agents of mycotoxinogenic fungi contaminating food and feed at storage. There are untapped potentials to interact with the accumulation of mycotoxins in cereals products, from the field to the final product. Extracts or purified metabolites from cultivable edible mushrooms having antifungal and/or antimycotoxin activities could be used as alternatives to fungicides in integrated crop protection strategies. Mycelium could be used as biocontrol agents being antagonists of mycotoxigenic fungi on crop debris. Mycelium could be used as degrader of mycotoxins in grains or straws and stalks and for enriching them in nutrients and antioxidant properties before their use as feed or food. Ultimately, edible mushrooms would be produced from contaminated materials that could not be detoxified.

\section{REFERENCES}

Ait-Lahsen, H., A. Soler, M. Rey, J. de la Cruz, E. Monte, A. LlobeII, 2001. An antifungal exo- $\alpha-1,3-$ glucanase (agn13.1) from the biocontrol fungus Trichoderma harzianum. Applied and Environmental Microbiology 67: 5833-5839.

Alberts, J.F., W.C.A. Gelderblom, A. Botha, W.H. Van Zyl, 2009. Degradation of aflatoxin B1 by fungal laccase enzymes. International Journal of Food Microbiology 135: 47-52.

Alvarez-Parrilla, E., L.A. de la Rosa, N.R. Martínez, G. A. Aguilar González, 2007. Total phenols and antioxidant activity of commercial and wild mushrooms from Chihuahua, Mexico. CYTA-Journal of Food 5: 329-334.

Alves, M.J., I.C.F.R Ferreira, J. Dias, V. Teixeira, A. Martins, M. Pintado, 2013. A review on antifungal activity of mushroom (basidiomycetes) extracts and isolated compounds. Current Topics in Medicinal Chemistry 13: 2648-2659.

Ansari, M.A., A. Anurag, Z. Fatima, S. Hameed, 2013. Natural phenolic compounds: a potential antifungal agent. In: Méndez-Vilas, A. (ed.), Microbial pathogens and strategies for combating them: science, technology and education. Formatex Research Center, Badajoz. Pp. 189-195.

Atanasova-Penichon, V., C. Barreau, F. Richard-Forget, 2016. Antioxidant secondary metabolites in cereals: potential involvement in resistance to Fusarium and mycotoxin accumulation. Frontiers in Microbiology 7: 566.

Atanasova-Penichon, V., S. Bernillon, G. Marchegay, A. Lornac, L. Pinson-Gadais, N. Ponts, E. Zehraoui, C. Barreau, F. Richard-Forget, 2014. Bioguided isolation, characterization and biotransformation by Fusarium verticillioides of maize kernel compounds that inhibit fumonisin production. Molecular Plant-Microbe Interactions 27: 1148-1158.

Baldrian, P., 2006. Fungal laccases-occurrence and properties. FEMS Microbiology Reviews 30: 215-242.

Banu, I., A. Lupu, I. Aprodu, 2013. Degradation of zearalenone by laccase enzyme. Scientific Study \& Research 14: 79-84.

Barros, L., M. Dueñas, I.C. Ferreira, P. Baptista, C. Santos-Buelga, 2009. Phenolic acids determination by HPLC-DAD-ESI/MS in sixteen different Portuguese wild mushrooms species. Food and Chemical Toxicology 47: 1076-1079.

Battilani, P., P. Toscano, H. Van der Fels-Klerx, A. Moretti, M. Camardo Leggieri, C. Brera, A. Rortais, T. Goumperis, T. Robinson, 2016. Aflatoxin B1 contamination in maize in Europe increases due to climate change. Scientific Reports 6: 24328.

Beekrum, S., R. Govinden, T. Padayachee, B. Odhav, 2003. Naturally occurring phenols: a detoxification strategy for fumonisin B1. Food Additives \& Contaminants 20: 490-493.

Benítez, T., C. Limón, J. Delgado-Jarana, M. Rey, 1998. Glucanolytic and other enzymes and their genes. In: Harman, G.E., C. Kubicek (eds.), Trichoderma and Gliocladium: enzymes, biological control and commercial applications. Taylor and Francis, London. Pp. 101-127.

Bernardo, D., A.P. Cabo, M. Novaes-Ledieu, C.G. Mendoza, 2004. Verticillium disease or "dry bubble" of cultivated mushrooms: the Agaricus bisporus lectin recognizes and binds the Verticillium fungicola cell wall glucogalactomannan. Canadian Journal of Microbiology 50: 729-735. 
Bilska, K., K. Stuper-Szablewska, T. Kulik, M. Buśko, D. Załuski, S. Jurczak, J. Perkowski, 2018. Changes in phenylpropanoid and trichothecene production by Fusarium culmorum and F. graminearum sensu stricto via exposure to flavonoids. Toxins 10: 110.

Bleuler-Martinez, S., S. Schmieder, M. Aebi, M. Künzler, 2012. Biotin-binding proteins in the defence of mushrooms against predators and parasites. Applied and Environmental Microbiology 78: 8485-8487.

Bollina, V., A.C. Kushalappa, 2011. In vitro inhibition of trichothecene biosynthesis in Fusarium graminearum by resistance-related endogenous metabolites identified in barley. Mycology 2: 291-296.

Boutigny, A.L., C. Barreau, V. Atanasova-Penichon, M.N. Verdal-Bonnin, L. Pinson-Gadais, F. Richard-Forget, 2009. Ferulic acid, an efficient inhibitor of type B trichothecene biosynthesis and Tri gene expression in Fusarium liquid cultures. Mycological Research 113: 746-753.

Branà, M.T., M.T. Cimmarusti, M. Haidukowski, A.F. Logrieco, C. Altomare, 2017. Bioremediation of aflatoxin B1-contaminated maize by king oyster mushroom (Pleurotus eryngii). PLoS ONE 12: e0182574.

Chang, B.V., S.N. Fan, Y.C. Tsai, Y.L. Chung, P.X. Tu, C.W. Yang, 2018. Removal of emerging contaminants using spent mushroom compost. Science of the Total Environment 634: 922-933.

Chang, S.T., P.G. Miles, 1992. Mushroom biology, a new discipline. Mycologist 6: 64-65.

Chen, J.T., J.W. Huang, 2009. Control of plant diseases with secondary metabolite of Clitocybe nuda. New Biotechnology 26: 193198.

Chen, W., C. Li, B. Zhang, Z. Zhou, Y. Shen, X. Liao, J. Yang, Y. Wang, X. Li, Y. Li, X.L. Shen, 2018. Advances in biodetoxification of ochratoxin A-A review of the past five decades. Frontiers in Microbiology 9: 1386.

Chu, K.T., L.X. Xia, T.B. Ng, 2005. Pleurostrin, an antifungal peptide from the oyster mushroom. Peptides 26: 2098-2103.

D'Mello, J.P.F., A.M.C. McDonald, R. Rinna, 2001. Effect of azoxystrobin on mycotoxin production in a carbendazim-resistant strain of Fusarium sporotrichioides. Phytoparasitica 29: 431-440.

Da Silva, E.O., A.P.F.L. Bracarense, I.P. Oswald, 2018. Mycotoxins and oxidative stress: where are we? World Mycotoxins Journal 11: 113-134.

Davitashvili, E., E. Kapanadze, E. Kachlishvili, T. Khardziani, V. Elisashvili, 2008. Evaluation of higher basidiomycetes mushroom lectin activity in submerged and solid-state fermentation of agro-industrial residues. International Journal of Medicinal Mushrooms 10: 171-179.

Davitashvili, E., E. Kapanadze, E. Kachlishvili, E. Metreveli, V. Elisashvili, 2010. Comparative study of the hemagglutinating activity of lectins isolated from different developmental stages of culinary-medicinal oyster mushroom, Pleurotus ostreatus (Jacq.: Fr.) Kumm. (Agaricomycetideae). International Journal of Medicinal Mushrooms 12: 43-50.

Davitashvili, E., E. Kapanadze, E. Kachlishvili, V. Elisashvili, 2011. Lectin activity of species of genus Cerrena S.F. Gray (Aphyllophoromycetideae) in submerged fermentation of lignocellulosic materials. International Journal of Medicinal Mushrooms 13: 159-166.
Dakshinamurti, K., S. Dakshinamurti, M.P. Czubryt, 2017. Effects of biotin deprivation and biotin supplementation. In: Preedy V., V. Patel (eds.), Handbook of famine, starvation, and nutrient deprivation. Springer, Cham. Pp. 1-21.

Deng, J.J., W.Q. Huang, Z.W. Li, D.L. Lu, Y. Zhang, X.C. Luo, 2018. Biocontrol activity of recombinant aspartic protease from Trichoderma harzianum against pathogenic fungi. Enzyme and Microbial Technology 112: 35-42.

Dors, G.C., S.S. Caldas, H.C. dos Santos Hackbart, E.G. Primel, C.A.A. Fagundes, E. Badiale-Furlong, 2013. Fungicides and the effects of mycotoxins on milling fractions of irrigated rice. Journal of Agricultural and Food Chemistry 61: 1985-1990.

Dubost, N.J., R.B. Beelman, D.J. Royse, 2007. Influence of selected cultural factors and postharvest storage on ergothioneine content of common button mushroom Agaricus bisporus (J. Lge) Imbach (Agaricomycetideae). International Journal of Medicinal Mushrooms 9: 163-176.

Dubos, T., M. Pasquali, F. Pogoda, L. Hoffmann, M. Beyer, 2011. Evidence for natural resistance towards trifloxystrobin in Fusarium graminearum. European Journal of Plant Pathology 130: 239248.

Dündar, A., V. Okumus, S. Özdemir, K.S. Çelik, M. Boga, E. Ozcagli, G. Ozhan, A. Yildiz, 2015. Antioxidant, antimicrobial, cytotoxic and anticholinesterase activities of seven mushroom species with their phenolic acid composition. Journal of Horticulture 2: 161.

Eisele, N., D. Linke, M. Nimtz, R.G. Berger, 2011. Heterologous expression, refolding and characterization of a salt activated subtilase from Pleurotus ostreatus. Process Biochemistry 46: 18401846.

Erjavec, J., J. Kos, M. Ravnikar, T. Dreo, J. Sabotič, 2012. Proteins of higher fungi-from forest to application. Trends in Biotechnology 30: 259-273.

Essig, A., D. Hofmann, D. Münch, S. Gayathri, M. Künzler, P. T. Kallio, H.G. Sahl, G. Wider, T. Schneider, M. Aebi, 2014. Copsin, a novel peptide-based fungal antibiotic interfering with the peptidoglycan synthesis. Journal of Biological Chemistry 289: 34953-34964.

Faraco, V., G. Palmieri, G. Festa, M. Monti, G. Sannia, P. Giardina, 2005. A new subfamily of fungal subtilases: structural and functional analysis of a Pleurotus ostreatus member. Microbiology 151: 457-466.

Ferreira, I.C.F.R., L. Barros, R.M.V. Abreu, 2009. Antioxidants in wild mushrooms. Current Medicinal Chemistry 16: 1543-1560.

Ferrochio, L., E. Cendoya, M.C. Farnochi, W. Massad, M.L. Ramírez, 2013. Evaluation of ability of ferulic acid to control growth and fumonisin production of Fusarium verticillioides and Fusarium proliferatum on maize based media. International Journal of Food Microbiology167: 215-220.

Ferruz, E., V. Atanasova-Pénichon, I M.N. Bonnin-Verda, G. Marchegay, L. Pinson-Gadais, C. Ducos, S. Lorán, A. Ariño, C. Barreau, F. Richard-Forget, 2016. Effects of phenolic acids on the growth and production of T-2 and HT-2 toxins by Fusarium langsethiae and F. sporotrichioides. Molecules 21: 449.

Gan, C.H., N.B. Amira, R. Asmah, 2013. Antioxidant analysis of different types of edible mushrooms (Agaricus bisporous and Agaricus brasiliensis). International Food Research Journal 20: 1095-1102. 
Gąsecka, M., Z. Magdziak, M. Siwulski, M. Mleczek, 2018. Profile of phenolic and organic acids, antioxidant properties and ergosterol content in cultivated and wild growing species of Agaricus. European Food Research and Technology 244: 259-268.

Gauthier, L., M.N. Verdal, G. Marchegay, L. Pinson-Gadais, C. Ducos, F. Richard-Forget, V. Atanasova-Penichon, 2016. Fungal biotransformation of chlorogenic and caffeic acids by Fusarium graminearum: new insights in the contribution of phenolic acids to resistance to deoxynivalenol accumulation in cereals. International Journal of Food Microbiology 221: 61-68.

Gil-Ramírez, A., C. Pavo-Caballero, E. Baeza, N. Baenas, C. Garcia-Viguera, F.R. Marín, C. Soler-Rivas, 2016. Mushrooms do not contain flavonoids. Journal of Functional Foods 25: 1-13.

Gilardoni, G., M. Clericuzio, S. Tosi, G. Zanoni, G. Vidari, 2007. Antifungal acylcyclopentenediones from fruiting bodies of Hygrophorus chrysodon. Journal of Natural Products 70: 137-139.

Guo, Y., H. Wang, T.B. Ng, 2005. Isolation of trichogin, an antifungal protein from fresh fruiting bodies of the edible mushroom Tricholoma giganteum. Peptides 26: 575-580.

Haidukowski, M., M. Pascale, G. Perrone, D. Pancaldi, C. Campagna, A. Visconti, 2005. Effect of fungicides on the development of Fusarium head blight, yield and deoxynivalenol accumulation in wheat inoculated under field conditions with Fusarium graminearum and Fusarium culmorum. Journal of the Science of Food and Agriculture 85: 191-198.

Han, J.R., 2003. Solid-state fermentation of cornmeal with the basidiomycete Hericium erinaceum for degrading starch and upgrading nutritional value. International Journal of Food Microbiology 80: 61-66.

Han, J.R., C.H. An, J.M. Yuan, 2005. Solid-state fermentation of cornmeal with the basidiomycete Ganoderma lucidum for degrading starch and upgrading nutritional value. Journal of Applied Microbiology 99: 910-915.

Heleno, S.A., L. Barros, A. Martins, M.J.R. Queiroz, C. Santos-Buelga, I.C. Ferreira, 2012. Fruiting body, spores and in vitro produced mycelium of Ganoderma lucidum from Northeast Portugal: a comparative study of the antioxidant potential of phenolic and polysaccharidic extracts. Food Research International 46: 135140.

Heleno, S.A., I.C. Ferreira, A.P. Esteves, A. Ćirić, J. Glamočlija, A. Martins, M. Soković, M.J. Queiroz, 2013. Antimicrobial and demelanizing activity of Ganoderma lucidum extract, p -hydroxybenzoic and cinnamic acids and their synthetic acetylated glucuronide methyl esters. Food and Chemical Toxicology 58: 95-100.

Hiscox, J., J. O'Leary, L. Boddy, 2018. Fungus wars: basidiomycete battles in wood decay. Studies in Mycology 89: 117-124.

Hong, S.Y., L.V. Roze, J. Wee, J.E. Linz, 2013. Evidence that a transcription factor regulatory network coordinates oxidative stress response and secondary metabolism in aspergilli. Microbiology Open 2: 144-160.

Jurado, M., P. Marín, N. Magan, M.T. González-Jaén, 2008. Relationship between solute and matric potential stress, temperature, growth, and FUM1 gene expression in two Fusarium verticillioides strains from Spain. Applied and Environmental Microbiology 74: 2032-2036.
Kelly, B.J., J.P. Langan, 2013. Method of myceliation of agricultural substates for producing functional foods and nutraceuticals. U.S. Patent No. 9,427,008.

Kim, J.H., B.C. Campbell, N. Mahoney, K. L. Chan, R.J. Molyneux, G.S. May, 2007. Enhanced activity of strobilurin and fludioxonil by using berberine and phenolic compounds to target fungal antioxidative stress response. Letters in Applied Microbiology 45: 134-141.

Kim, M.Y., P. Seguin, J.K. Ahn, J.J. Kim, S.C. Chun, E.H. Kim, S.H. Seo, E.Y. Kang, S.L. Kim, Y.J. Park, H.M. Ro, I.M. Chung, 2008. Phenolic compound concentration and antioxidant activities of edible and medicinal mushrooms from Korea. Journal of Agricultural and Food Chemistry 56: 7265-7270.

Lahouar, A., S. Marin, A. Crespo-Sempere, S. Saïd, V. Sanchis, 2016. Effects of temperature, water activity and incubation time on fungal growth and aflatoxin B1 production by toxinogenic Aspergillus flavus isolates on sorghum seeds. Revista Argentina de Microbiología 48, 78-85.

Lam, S.K., T.B. Ng, 2001a. Hypsin, a novel thermostable ribosome-inactivating protein with antifungal and antiproliferative activities from fruiting bodies of the edible mushroom Hypsizigus marmoreus. Biochemical and Biophysical Research Communications 285: 1071-1075.

Lam, S.K., T.B. Ng, 2001b. First simultaneous isolation of a ribosome inactivating protein and an antifungal protein from a mushroom (Lyophyllum shimeji) together with evidence for synergism of their antifungal effects. Archives of Biochemistry and Biophysics 393: 271-280.

Largeteau, M.L., J.M. Savoie, 2010. Microbially-induced diseases of Agaricus bisporus: biochemical mechanisms and impact on commercial mushroom production. Applied Microbiology and Biotechnology 86: 63-73.

Largeteau, M.L., P. Callac, A.M. Navarro-Rodriguez, J.M. Savoie, 2011. Diversity in the ability of Agaricus bisporus wild isolates to fruit at high temperature $\left(25^{\circ} \mathrm{C}\right)$. Fungal Biology 115 : 1186 1195.

Legrand, F., A. Picot, J.F. Cobo-Díaz, W. Chen, G. Le Floch, 2017. Challenges facing the biological control strategies for the management of Fusarium head blight of cereals caused by F. graminearum. Biological Control 113: 26-38.

Leplat, J., H. Friberg, M. Abid, C. Steinberg, 2013. Survival of Fusarium graminearum, the causal agent of Fusarium head blight. A review. Agronomy for Sustainable Development 33: 97-111.

Li, H.B., M.Y. Wang, L.B. Hu, H.Z. Mo, D.D. Pan, 2015. Structural Identification of Lentinus edodes cellulose derivative that inhibits aflatoxin production by Aspergillus flavus. Tropical Journal of Pharmaceutical Research 14 : 495-501.

Li, J., F. Gu, R. Wu, J. Yang, K.Q. Zhang, 2017. Phylogenomic evolutionary surveys of subtilase superfamily genes in fungi. Scientific Reports 7: 45456.

Lin, P., J.H. Wong, T.B. Ng, 2010. A defensin with highly potent antipathogenic activities from the seeds of purple pole bean. Bioscience Reports 30: 101-109.

Loi, M., F. Fanelli, P. Zucca, V.C. Liuzzi, L. Quintieri, M.T. Cimmarusti, L. Monaci, M. Miriam Haidukowski, A.F. Logrieco, E. 
Sanjust, G. Mulè, 2016. Aflatoxin B1 and M1 degradation by Lac2 from Pleurotus pulmonarius and redox mediators. Toxins 8: 245-261.

Loi, M., F. Fanelli, V.C. Liuzzi, A.F. Logrieco, G. Mulè, 2017. Mycotoxin biotransformation by native and commercial enzymes: present and future perspectives. Toxins 9: 111.

Loi, M., F. Fanelli, M.T. Cimmarusti, V. Mirabelli, M. Haidukowski, A.F. Logrieco, R. Caliandro, G. Mulè, 2018. In vitro single and combined mycotoxins degradation by Ery4 laccase from Pleurotus eryngii and redox mediators. Food Control 90: 401-406.

Loos, R., A. Belhadj, M. Menez, 2004. Occurrence and distribution of Microdochium nivale and Fusarium species isolated from barley, durum and soft wheat grains in France from 2000 to 2002. Mycopathologia 158: 351-362.

López-Vázquez, E., F. Prieto-García, M. Gayosso-Canales, E.O. Sánchez, J.V. Ibarra, 2017. Phenolic acids, flavonoids, ascorbic acid, $\beta$-glucans and antioxidant activity in mexican wild edible mushrooms. Italian Journal of Food Science 29: 766-774.

Luo, D.Q., F. Wang, X.Y. Bian, J.K. Liu, 2005. Rufuslactone, a new antifungal sesquiterpene from the fruiting bodies of the basidiomycete Lactarius rufus. The Journal of Antibiotics 58: 456-459.

Luongo, L., M. Galli, L. Corazza, E. Meekes, L.D. Haas, C.L. Van Der Plas, J. Köhl, 2005. Potential of fungal antagonists for biocontrol of Fusarium spp. in wheat and maize through competition in crop debris. Biocontrol Science and Technology 15: 229-242.

Magan, N., M.P. Challen, T.J. Elliot, 1995. Osmotic, matric potential and temperature effects in vitro growth of Agaricus bisporus and A. bitorquis strains. In: Elliot T.J. (ed.), Science and cultivation of edible fungi. Balkema, Rotterdam. Pp. 773-780.

Maggio-Hall, L.A., R.A. Wilson, N.P. Keller, 2005. Fundamental contribution of $\beta$-oxidation topolyketide mycotoxin production in planta. Molecular Plant-Microbe Interactions 18: 783-793.

Marin, S., V. Sanchis, N. Magan, 1995. Water activity, temperature and $\mathrm{pH}$ effects on growth of Fusarium moniliforme and F. proliferatum isolates from maize. Canadian Journal of Microbiology 41: 1063-1070.

Martinez Tuppia, C., V. Atanasova-Penichon, S. Chéreau, N. Ferrer, G. Marchegay, J.M. Savoie, F. Richard-Forget, 2017. Yeast and bacteria from ensiled high moisture maize grains as potential mitigation agents of fumonisin B1. Journal of the Science of Food and Agriculture 97: 2443-2452.

Martins, N.F., E. Bresso, R.C. Togowa, M. Urban, J. Antoniw, B. Maigret, K. Hammond-Kosack, 2016. Searching for novel targets to control wheat Head Blight Disease-I-Protein identification, 3D modelling and virtual screening. Advances in Microbiology 6: 811-830.

Mata, G., J.M. Savoie, P. Delpech, J.M. Olivier, 1998. Reductions of the incidence of Trichoderma spp. using substrate supplementation with peat and an alternative spawn during cultivation of Lentinula edodes on pasteurised straw. Agronomie 18: 515-520.

McCormick, S.P., 2013. Microbial detoxification of mycotoxins. Journal of Chemical Ecology 39: 907-918.

Mierziak, J., K. Kostyn, A. Kulma, 2014. Flavonoids as important molecules of plant interactions with the environment. Molecules 19: 16240-16265.
Mikiashvili, N.A., V. Elisashvili, S.P. Wasser, E. Nevo, 2006. Comparative study of lectin activity of higher basidiomycetes. International Journal of Medicinal Mushrooms 1: 31-38.

Mohd Hanafi, F.H., S. Rezania, S. Mat Taib, M.F. Md Din, M. Yamauchi, M. Sakamoto, H. Hara, J. Park, S.S. Ebrahimi, 2018. Environmentally sustainable applications of agro-based spent mushroom substrate (SMS): an overview. Journal of Material Cycles and Waste Management 20: 1383-1396.

Mohsen, S.F., M.A. Abbassy, E.I. Rabea, H.K. Abou-Taleb, 2018. Isolation and antifungal activity of plant lectins against some plant pathogenic fungi. Alexandria Science Exchange Journal 39: 161167.

Money, N.P., 2016. Are mushrooms medicinal? Fungal Biology 120: 449-453.

Montibus, M., C. Ducos, M.-N. Bonnin-Verdal, J. Bormann, N. Ponts, F. Richard Forget, C. Barreau, 2013.The bZIP transcription factor Fgap1 mediates oxidative stress response and trichothecene biosynthesis but not virulence in Fusarium graminearum. PLoS ONE 8: e83377.

Motomura, M., T. Toyomasu, K. Mizuno, T. Shinozawa, 2003. Purification and characterization of an aflatoxin degradation enzyme from Pleurotus ostreatus. Microbiological Research 158: 237-42.

Muszyńska, B, K. Kała, K. Sułkowska-Ziaja, A. Szewczyk, M. Łojewski, J. Rojowski, 2015. Analysis of the content of phenolic compounds in in vitro culture of some edible mushrooms (Basidiomycota). Medicina Internacia Revuo 26: 146-152.

Ng, T.B., R.C.F. Cheung, J.H. Wong, Y.S. Chan, X. Dan, W. Pan, H. Wang, S. Guan, K. Chan, X.Y. Ye, F. Liu, L. Xia, W.Y. Chan, 2016. Fungal proteinaceous compounds with multiple biological activities. Applied Microbiology and Biotechnology 100: 6601-6617.

Ngai, P.H.K., T.B. Ng, 2003. Lentin, a novel and potent antifungal protein from shitake mushroom with inhibitory effects on activity of human immunodeficiency virus-1 reverse transcriptase and proliferation of leukemia cells. Life Sciences 73: 3363-3374.

Ngai, P.H.K., Ng, T.B. 2004. A ribonuclease with antimicrobial, antimitogenic and antiproliferative activities from the edible mushroom Pleurotus sajor-caju. Peptides 25: 11-17

Ngai, P.H.K., Z. Zhao, T.B. Ng, 2005. Agrocybin, an antifungal peptide from the edible mushroom Agrocybe cylindracea. Peptides 26: 191-196.

Nikitina, V.E., E.A. Loshchinina, E.P. Vetchinkina, 2017. Lectins from mycelia of basidiomycetes. International Journal of Molecular Sciences 18: 1334.

Nowacka, N., R. Nowak, M. Drozd, M. Olech, R. Los, A. Malm, 2014. Analysis of phenolic constituents, antiradical and antimicrobial activity of edible mushrooms growing wild in Poland. LWT - Food Science and Technology 59: 689-694.

Oka, K., A. Ishihara, N. Sakaguchi, S. Nishino, R.Y. Parada, A. Nakagiri, H. Otani, 2015. Antifungal activity of volatile compounds produced by an edible mushroom Hypsizygus marmoreus against phytopathogenic fungi. Journal of Phytopathology 163: 987-996.

Okull, D.O., R.B. Beelman, H. Gourama, 2003. Antifungal activity of 10-oxo-trans-8-decenoic acid and 1-octen-3ol against Penicillium expansum in potato dextrose agar medium. Journal of Food Protection 66: 1503-1505. 
Othman, A.M., M.A. Elsayed, A. M. Elshafei, M.M. Hassan, 2018. Purification and biochemical characterization of two isolated laccase isoforms from Agaricus bisporus CU13 and their potency in dye decolorization. International Journal of Biological Macromolecules 113: 1142-1148.

Palacios, I., M. Lozano, C. Moro, M. D’Arrigo, M.A. Rostagno, J.A. Martínez, A. García-Lafuente, E. Guillamón, 2011. Antioxidant properties of phenolic compounds occurring in edible mushrooms. Food Chemistry 128: 674-678.

Palazzini, J.M., N. Yerkovicha, E. Alberione, M. Chiotta, S.N. Chulze, 2017. An integrated dual strategy to control Fusarium graminearum sensu stricto by the biocontrol agent Streptomyces sp. RC 87B under field conditions. Plant Gene 9: 13-18.

Pani, G., B. Scherm, E. Azara, V. Balmas, Z. Jahanshiri, P. Carta, D. Fabbri, M.A. Dettori, A. Fadda, A. Dessì, R. Dallocchio, Q. Migheli, G. Delogu, 2014. Natural and natural-like phenolic inhibitors of type $B$ trichothecene in vitro production by the wheat (Triticum sp.) pathogen Fusarium culmorum. Journal of Agricultural and Food Chemistry 62: 4969-4978.

Park, B.T., K.H. Na, E.C. Jung, J.W. Park, H.H. Kim, 2009. Antifungal and anticancer activities of a protein from the mushroom Cordyceps militaris. Korean Journal of Physiology and Pharmacology 13: 49-54.

Peng, Z., L. Chen, Y. Zhu, Y. Huang, X. Hu, Q. Wu, W. Yang, 2018. Current major degradation methods for aflatoxins: a review. Trends in Food Science and Technology 80: 155-156.

Philippoussis, A., P. Diamantopoulou, 2011. Agro-food industry wastes and agricultural residues conversion into high value products by mushroom cultivation. In: Savoie, J.M., M. Foulongne-Oriol, M. Largeteau, G. Barroso (eds.), Proceedings of the 7th international conference on mushroom biology and mushroom products (ICMBMP7). Arcachon, France. Pp. 339-351.

Picot, A., V. Atanasova-Pénichon, S. Pons, G. Marchegay, C. Barreau, L. Pinson-Gadais, J. Roucolle, F. Daveau, D. Caron, F. Richard-Forget, 2013. Maize kernel antioxidants and their potential involvement in Fusarium Ear Rot resistance. Journal of Agricultural and Food Chemistry 61: 3389-3395.

Ponts N., 2015. Mycotoxins are a component of Fusarium graminearum stress-response system. Frontiers in Microbiology 6: 1234.

Ponts, N., L. Pinsons-Gadais, A.L. Boutigny, C. Barreau, F. Richard-Forget, 2011. Cinnamic-derived acids significantly affect Fusarium graminearum growth and in vitro synthesis of type B trichothecenes. Phytopathology 101: 929-934.

Ramirez, M.L., S. Chulze, N. Magan, 2006. Temperature and water activity effects on growth and temporal deoxynivalenol production by two Argentinean strains of Fusarium graminearum on irradiated wheat grain. International Journal of Food Microbiology 106: 291-296.

Reis, F.S., A. Martins, L. Barros, I.C.F.R. Ferreira, 2012a. Antioxidant properties and phenolic profile of the most widely appreciated cultivated mushrooms: a comparative study between in vivo and in vitro samples. Food and Chemical Toxicology 50: 1201-1207.

Reis, F.S., L. Barros, R.C. Calhelha, A. Ćirić, L.J. Van Griensven, M. Soković, I.C. Ferreira, 2013. The methanolic extract of Cordyceps militaris (L.) Link fruiting body shows antioxidant, antibacte- rial, antifungal and antihuman tumor cell lines properties. Food and Chemical Toxicology 62: 91-99.

Reis, F.S., D. Stojković, M. Soković, J. Glamočija, A. Ćirić, L. Barros, I.C.F.R. Ferreira, 2012b. Chemical characterization of Agaricus bohusii, antioxidant potential and antifungal preserving properties when incorporated in cream cheese. Food Research International 48: 620-626.

Reverberi, M., F. Di Mario, U. Tomati, 2004. $\beta$-Glucan synthase induction in mushrooms grown on olive mill wastewaters. Applied Microbiology and Biotechnology 66 : 217-225.

Reverberi, M., A.A. Fabbri, S. Zjalic, A. Ricelli, F. Punelli, C. Fanelli, 2005. Antioxidant enzymes stimulation in Aspergillus parasiticus by Lentinula edodes inhibits aflatoxin production. Applied Microbiology and Biotechnology 69: 207-215.

Reverberi, M., S. Zjalic, A. Ricelli, A.A. Fabbri, C. Fanelli, 2006. Oxidant/antioxidant balance in Aspergillus parasiticus affects aflatoxin biosynthesis. Mycotoxin Research 22: 39-47.

Reverberi, M., S. Zjalic, A. Ricelli, F. Punelli, E. Camera, C. Fabbri, M. Picardo, C. Fanelli, A.A. Fabbri, 2008. Modulation of antioxidant defense in Aspergillus parasiticus is involved in aflatoxin biosynthesis: a role for the ApyapA gene. Eukaryotic Cell 7: 988-1000.

Rodrigues A.G., 2016. Secondary metabolism and antimicrobial metabolites of Aspergillus. In: Gupta, V.K. (ed.), New and future developments in microbial biotechnology and bioengineering. Aspergillus system properties and applications. Elsevier, Oxford. Pp. 81-86.

Ryan, C.A., 1987. Oligosaccharide signalling in plants. Annual Review of Cell Biology 3: 295-317.

Sabotič, J., T. Trček, T. Popovič, J. Brzin, 2007. Basidiomycetes harbour a hidden treasure of proteolytic diversity. Journal of Biotechnology 128: 297-307.

Samapundo, S., F. Devlieghere, B. De Meulenaer, A.H. Geeraerd, J.F. Van Impe, J.M. Debevere, 2005. Predictive modelling of the individual and combined effect of water activity and temperature on the radial growth of Fusarium verticilliodes and F. proliferatum on corn. International Journal of Food Microbiology 105: 35-52.

Sánchez C., 2004. Modern aspects of mushroom culture technology. Applied Microbiology and Biotechnology 64: 756-762.

Sarrocco, S., G. Vannacci, 2018. Preharvest application of beneficial fungi as a strategy to prevent postharvest mycotoxin contamination: a review. Crop Potection 110: 160-170.

Savoie, J.M., 2008. Reactive oxygen species and the strategy of antioxidant defence in mushrooms. In: Lelley, J.L., J.A. Buswell (eds.). Proceedings of the sixth international conference on mushroom biology and mushroom products. GAMU, Krefeld. Pp. 8-20.

Savoie, J.M., N. Minvielle, M.L. Largeteau, 2008. Radical-scavenging properties of extracts from the white button mushroom, Agaricus bisporus. Journal of the Science of Food and Agriculture 88: 970-975.

Savoie, J.M., M. Foulongne Oriol, G. Barroso, P. Callac, 2013. Genetics and genomics of cultivated mushrooms, application to breeding of Agarics. In: Kempken, F. (ed.), Agricultural Applications. Springer, Berlin. Pp 3-33. 
Scaglioni, P.T., S. de Oliveira Garcia, E. Badiale-Furlong, 2018. Inhibition of in vitro trichothecenes production by microalgae phenolic extracts. Food Research International 124: 175-180.

Scarpari, M., C. Bello, C. Pietricola, M. Zaccaria, L. Bertocchi, A. Angelucci, M. Reverberi, 2014. Aflatoxin control in maize by Trametes versicolor. Toxins 6: 3426-3437.

Scarpari, M., A. Parroni, M. Zaccaria, L. Fattorini, C. Bello, A.A. Fabbri, G. Bianchi, V. Scala, S. Zjalic, C. Fanelli, 2016. Trametes versicolor bioactive compounds stimulate Aspergillus flavus antioxidant system and inhibit aflatoxin synthesis. Plant Biosystems 150: 653-659.

Scarpino, V., A. Reyneri, M. Sulyok, R. Krska, M. Blandino, 2015. Effect of fungicide application to control Fusarium head blight and 20 Fusarium and Alternaria mycotoxins in winter wheat (Triticum aestivum L.). World Mycotoxin Journal 8: 499-510.

Shah, L., A. Ali, M. Yahya, Y. Zhu, S. Wang, H. Si, C. Ma, 2018. Integrated control of Fusarium head blight and deoxynivalenol mycotoxin in wheat. Plant Pathology 67: 532-548.

Shen, H.S., S. Shao, J.C. Chen, T. Zhou, 2017. Antimicrobials from mushrooms for assuring food safety. Comprehensive Reviews in Food Science and Food Safety 16: 316-329.

Silva, P.M., S. Gonçalves, N.C. Santos, 2014. Defensins: antifungal lessons from eukaryotes. Frontiers in Microbiology 5: 97.

Singh A.K., H.S. Chhatpar, 2011. Purification, characterization and thermodynamics of antifungal protease from Streptomyces sp. A6. Journal of Basic Microbiology 51: 424-432.

Sivanandhan S., A. Khusro, M.G. Paulraj, S. Ignacimuthu, N.A. AL-Dhabi, 2017. Biocontrol properties of basidiomycetes: an overview. Journal of Fungi 3: 2.

Spremo, N.R., K.D. Tesanović, M.S. Rakić, L.N. Janjušević, M.V. Ignjatov, D.Đ. Bjelić, M.A. Karaman, 2017. Antifungal activity of macrofungi extracts on phytopathogenic fungal strains of genera Fusarium sp. and Alternaria sp. Matica Srpska Journal for Natural Sciences 133: 231-234.

Takakura, Y., N. Oka, J. Suzuki, H. Tsukamoto, Y. Ishida, 2012. Intercellular production of tamavidin 1 , a biotin-binding protein from tamogitake mushroom, confers resistance to the blast fungus Magnaporthe oryzae in transgenic rice. Molecular Biotechnology 51: 9-17.

Thevissen, K., A. Ghazi, G.W. De Samblanx, C. Brownlee, R.W. Osborn, W.F. Broekaert, 1996. Fungal membrane responses induced by plant defensins and thionins. Journal of Biological Chemistry 271: 15018-15025.

Tolaini, V., S. Zjalic, M. Reverberi, C. Fanelli, A.A. Fabbri, A. Del Fiore, A. Ricelli, 2010. Lentinula edodes enhances the biocontrol activity of Cryptococcus laurentii against Penicillium expansum contamination and patulin production in apple fruits. International Journal of Food Microbiology 138: 243-249.

Vaz, J.A., L. Barros, A. Martins, J.S. Morais, M.H. Vasconcelos, I.C. Ferreira, 2011. Phenolic profile of seventeen Portuguese wild mushrooms. LWT - Food Science and Technology 44: 343-346.

Vetchinkina, E.P., N.N. Pozdnyakova, V.E. Nikitina, 2008. Laccase and lectin activities of intracellular proteins produced in a submerged culture of the xylotrophic basidiomycete Lentinus edodes. Current Microbiology 57: 381-385.
Vincelli, P., 2002. Qol (strobilurin) fungicides: benefits and risks. Plant Health Instructor. DOI: 10.1094/PHI-I-2002-0809-02

Walker, A.S., C. Auclair, M. Gredt, P. Leroux, 2009. First occurrence of resistance to strobilurin fungicides in Microdochium nivale and Microdochium majus from French naturally infected wheat grains. Pest Management Science 65: 906-915.

Wang, H.X., T.B. Ng, 2000. Flammulin: a novel ribosome-inactivating protein from fruiting bodies of the winter mushroom Flammulina velutipes. Biochemistry and Cell Biology 78: 699-702.

Wang, H.X., T.B. Ng, 2001. Isolation of pleuturegin, a novel ribosome-inactivating protein from fresh sclerotia of the edible mushroom Pleurotus tuber-regium. Biochemical and Biophysical Research Communications 288: 718-721.

Wang, H., T.B. Ng, 2004. Eryngin, a novel antifungal peptide from fruiting bodies of the edible mushroom Pleurotus eryngii. Peptides 25: 1-5.

Wang, H., T.B. Ng, Q. Liu, 2004. Alveolarin, a novel antifungal polypeptide from the wild mushroom Polyporus alveolaris. Peptides 25: 693-696.

Wang, H., T.B. Ng, 2006. Ganodermin, an antifungal protein from fruiting bodies of the medicinal mushroom Ganoderma lucidum. Peptides 27: 27-30.

Wang, J., H. Wang, X.M. Xia, P.P. Li, K.Y. Wang, 2013. Synergistic effect of Lentinula edodes and Pichia membranefaciens on inhibition of Penicillium expansum infections. Postharvest Biology and Technology 81: 7-12.

Wei, Q., Y. Liao, Y. Chen, S.H. Wang, Y. Xu, L. Tang, F. Chen, 2005. Isolation, characterisation and antifungal activity of $\beta-1,3-g l u-$ canase from seeds of Jatropha curcas. South African Journal of Botany 71: 95-99.

Wilson, N.M., N. McMaster, D. Gantulga, C. Soyars, S.P. McCormick, K. Knott, D.G. Schmale, 2017. Modification of the mycotoxin deoxynivalenol using microorganisms isolated from environmental samples. Toxins 9: 141

Wong, J.H., T.B. Ng, R.C. Cheung, X.J. Ye, H.X. Wang, S.K. Lam, L.X. $X i a, 2010$. Proteins with antifungal properties and other medicinal applications from plants and mushrooms. Applied Microbiology and Biotechnology 87: 1221-1235.

Wong, J.H., T.B. Ng, H. Wang, S.C.W. Sze, K.Y. Zhang, Q. Li, X. Lu, 2011. Cordymin, an antifungal peptide from the medicinal fungus Cordyceps militaris. Phytomedicine 18: 387-392.

Xue, A.G., Y.H. Chen, S.M.R. Sant'anna, H.D. Voldeng, G. Fedak, M.E. Savard, G.E. Harman, 2014. Efficacy of CLO-1 biofungicide in suppressing perithecial production by Gibberella zeae on crop residues. Canadian Journal of Plant Pathology 36: 161-169.

Yahia, E.M., F. Gutiérrez-Orozco, M.A. Moreno-Pérez, 2017. Identification of phenolic compounds by liquid chromatography-mass spectrometry in seventeen species of wild mushrooms in central Mexico and determination of their antioxidant activity and bioactive compounds. Food Chemistry 226: 14-22.

Yehia, R.S., 2014. Aflatoxin detoxification by manganese peroxidase purified from Pleurotus ostreatus. Brazilian Journal of Microbiology 45: 127-133.

Zervakis, G., A. Philippoussis, S. Ioannidou, P. Diamantopoulou, 2001. Mycelium growth kinetics and optimal temperature condi- 
tions for the cultivation of edible mushroom species on lignoceIlulosic substrates. Folia Microbiologica 46: 231-234.

Zhai F.H., Q. Wang, J.R. Han, 2015. Nutritional components and antioxidant properties of seven kinds of cereals fermented by the basidiomycete Agaricus blazei. Journal of Cereal Science 65: 202-208.

Zhao, X., Q.Q. Zhi, J.Y. Li, P. Nancy, N. P. Keller, Z.M. He, 2018. The antioxidant gallic acid inhibits aflatoxin formation in Aspergillus flavus by modulating transcription factors FarB and CreA. Toxins 10: 270 .
Zhu, Y., Y.I. Hassan, D. Lepp, S. Shao, T. Zhou, 2017. Strategies and methodologies for developing microbial detoxification systems to mitigate mycotoxins. Toxins 9: 130.

Zjalic, S., M. Reverberi, A. Ricelli, V.M. Granito, C. Fanelli, A.A. Fabbri, 2006. Trametes versicolor, a possible tool for aflatoxin control. International Journal of Food Microbiology 107: 243249. 